BMC

Evolutionary Biology

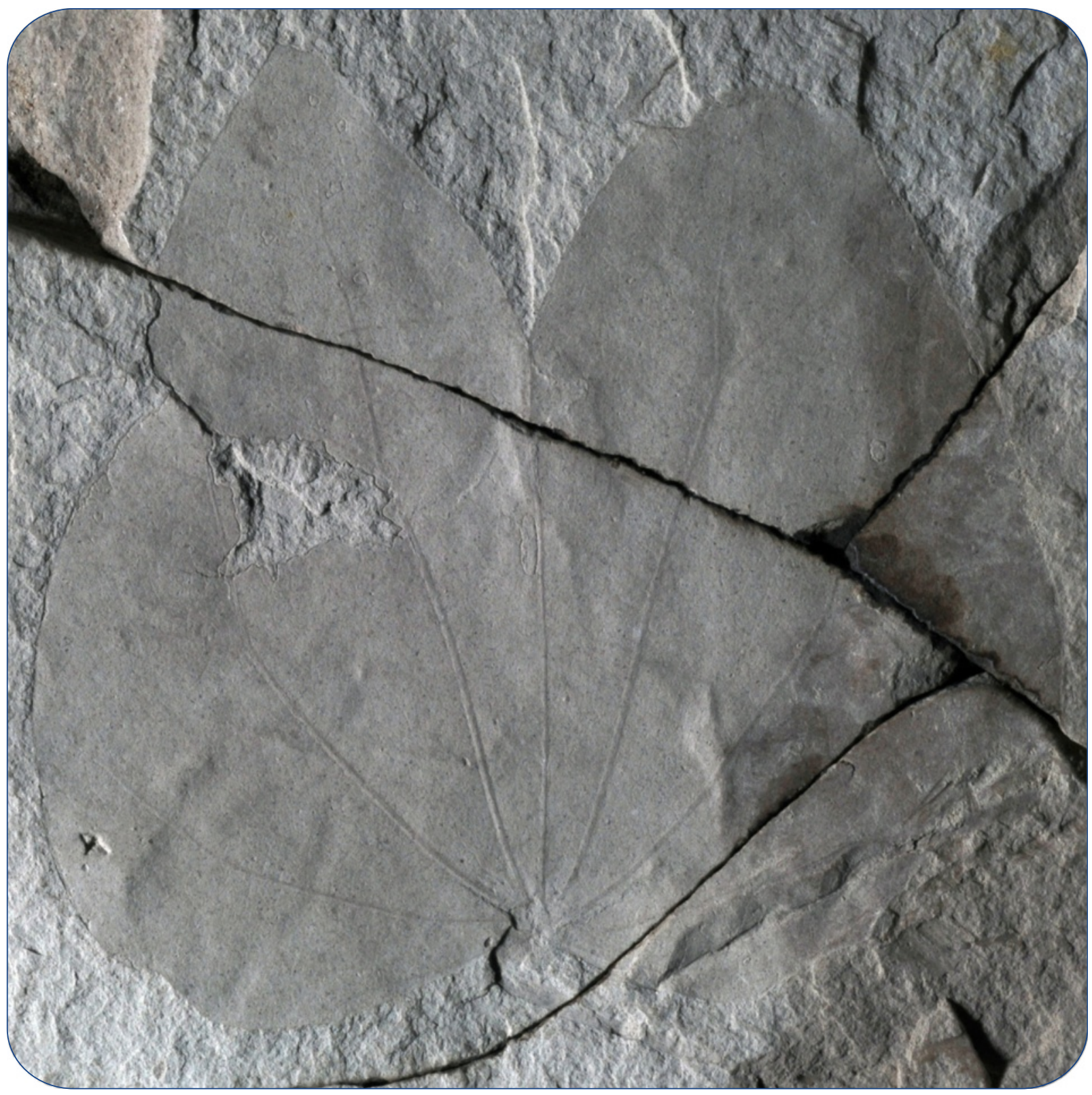

Bilobate leaves of Bauhinia (Leguminosae, Caesalpinioideae, Cercideae) from the middle Miocene of Fujian Province, southeastern China and their biogeographic implications

Lin et al. 


\title{
Bilobate leaves of Bauhinia (Leguminosae, Caesalpinioideae, Cercideae) from the middle Miocene of Fujian Province, southeastern China and their biogeographic implications
}

Yanxiang Lin ${ }^{1,2}$, William Oki Wong ${ }^{1 *}$, Gongle Shi ${ }^{3^{*}}$, Si Shen ${ }^{1}$ and Zhenyu $\mathrm{Li}^{1^{*}}$

\begin{abstract}
Background: Morphological and molecular phylogenetic studies suggest that the pantropical genus Bauhinia L. s.l. (Bauhiniinae, Cercideae, Leguminosae) is paraphyletic and may as well be subdivided into nine genera, including Bauhinia L. S.s. and its allies. Their leaves are usually characteristic bilobate and are thus easily recognized in the fossil record. This provides the opportunity to understand the early evolution, diversification, and biogeographic history of orchid trees from an historical perspective under the framework of morphological and molecular studies.

Results: The taxonomy, distribution, and leaf architecture of Bauhinia and its allies across the world are summarized in detail, which formed the basis for classifying the bilobate leaf fossils and evaluating the fossil record and biogeography of Bauhinia. Two species of Bauhinia are described from the middle Miocene Fotan Group of Fujian Province, southeastern China. Bauhinia ungulatoides sp. nov. is characterized by shallowly to moderately bilobate, pulvinate leaves with shallowly cordate bases and acute apices on each lobe, as well as paracytic stomatal complexes. Bauhinia fotana F.M.B. Jacques et al. emend. possesses moderately bilobate, pulvinate leaves with moderately to deeply cordate bases and acute or slightly obtuse apices on each lobe.

(Continued on next page)
\end{abstract}

\footnotetext{
* Correspondence:

happyking@ibcas.ac.cn; glshi@nigpas.ac.cn; lizy@ibcas.ac.cn

${ }^{1}$ State Key Laboratory of Systematic and Evolutionary Botany, Institute of Botany, Chinese Academy of Sciences, Beijing 100093, P.R. China

${ }^{3}$ State Key Laboratory of Palaeobiology and Stratigraphy, Nanjing Institute of Geology and Palaeontology, Chinese Academy of Sciences, 39 East Beijing Road, Nanjing 210008, P.R. China

Full list of author information is available at the end of the article
} 
(Continued from previous page)

Conclusions: Bilobate leaf fossils Bauhinia ungulatoides and B. fotana together with other late Paleogene - early Neogene Chinese record of the genus suggest that Bauhinia had been diverse in South China by the late Paleogene. Their great similarities to some species from South America and South Asia respectively imply that Bauhinia might have undergone extensive dispersals and diversification during or before the Miocene. The fossil record, extant species diversity, as well as molecular phylogenetic analyses demonstrate that the Bauhiniinae might have originated in the Paleogene of low-latitudes along the eastern Tethys Seaway. They dispersed southwards into Africa, migrated from Eurasia to North America via the North Atlantic Land Bridge or floating islands during the Oligocene. Then the genus spread into South America probably via the Isthmus of Panama since the Miocene onward, and underwent regional extinctions in the Boreotropics of mid-high-latitudes during the Neogene climatic cooling. Hence, Bauhinia presently exhibits a pantropical intercontinental disjunct distribution.

Keywords: Bauhinia, Bauhiniinae, Bilobate leaves, Biogeography, Caesalpinioideae, Cercideae, Evolution, Fotan Group, Legumes, Leguminosae, Miocene, North Atlantic Land Bridge, Orchid trees, Pantropical intercontinental disjunct, South China, Tethys Seaway

\section{Background}

Leguminosae Juss. are the third largest angiosperm family with various growth habits across different habitats of the world, including about 751 extant genera and ca. 19,500 species [1-3]. Traditionally, the family is divided into three subfamilies, i.e., Caesalpinioideae DC., Mimosoideae DC., and Papilionoideae L. ex DC. [4, 5]. Advances in legume systematics during recent decades, however, have challenged this traditional classification scheme and also the circumscription of some large legume genera [1,3]. Bauhinia L. s.l. (commonly known as the orchid tree), being a pantropical large genus with 340 species in the tribe Cercideae Bronn, is among the legumes with such a problem. Historical factors have complicated the taxonomy and nomenclature of Bauhinia [6-11]. Recent molecular phylogenetic and palynological studies have revealed that Bauhinia L. s.l. is not monophyletic [2, 12-14] and may as well be split into nine separate genera, including Bauhinia L. s.s., Barklya
F. Muell., Gigasiphon Drake, Lasiobema (Korth.) Miq., Lysiphyllum (Benth.) de Wit, Phanera Lour., Piliostigma Hochst., Schnella Raddi, and Tylosema (Schweinf.) Torre et Hillc. [6-11, 15-22] (Fig. 1; Table 1; see Additional file 1). We adopt this classification scheme, and these genera are referred to as "Bauhinia and its allies" in the present study.

Phylogenetic relationships as well as divergence times of Bauhinia and its allies have been inferred by molecular analyses [12, 13] (Fig. 1). However, the scenarios of their diversification and migratory routes through time are little known due to the lack of a comprehensive study of the fossil record of Bauhinia. Bauhinia and its allies in the subtribe Bauhiniinae (Benth.) Walp. usually bear bilobate and bifoliolate leaves with pulvinate petiole and basal actinodromous or acrodromous venation [23-27] (Fig. 2I-CII; see Additional file 2), which are easily recognized in the fossil record (Fig. 2CIII-CXVII; see Additional file 2). Bauhinia and Bauhinia-like bilobate and bifoliolate leaf fossils

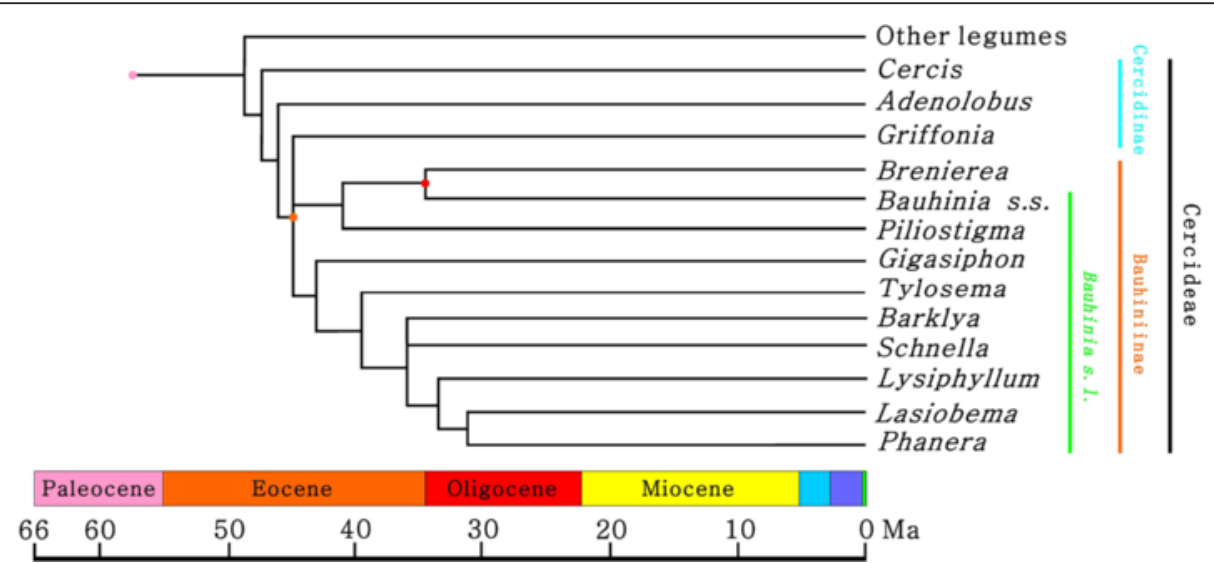

Fig. 1 A simplified diagram showing the phylogenetic relationships and divergence times of Bauhinia L. S.S. and its allies (after [12, 13]). Nodes of the cladogram refer to key leaf fossils [28-31] and the latest International Chronostratigraphic Chart [58] 
Table 1 A comparison of habit, floral part, distribution and species diversity between Bauhinia and its allies [9-11, 15-22]

\begin{tabular}{|c|c|c|c|c|c|c|c|c|c|}
\hline $\begin{array}{l}\text { Taxon } \\
\text { name }\end{array}$ & Bauhinia L. S.s. & $\begin{array}{l}\text { Barklya F. } \\
\text { Muell. }\end{array}$ & $\begin{array}{l}\text { Gigasiphon } \\
\text { Drake }\end{array}$ & $\begin{array}{l}\text { Lasiobema } \\
\text { (Korth.) Miq. }\end{array}$ & $\begin{array}{l}\text { Lysiphyllum } \\
\text { (Benth.) de Wit }\end{array}$ & Phanera Lour. & $\begin{array}{l}\text { Piliostigma } \\
\text { Hochst. }\end{array}$ & Schnella Raddi & $\begin{array}{l}\text { Tylosema } \\
\text { (Schweinf.) Torre } \\
\text { et Hillc. }\end{array}$ \\
\hline Type & $\begin{array}{l}\text { Bauhinia } \\
\text { divaricata L. }\end{array}$ & $\begin{array}{l}\text { Barklya syringifolia } \\
\text { F. Muell. }\end{array}$ & $\begin{array}{l}\text { Gigasiphon } \\
\text { humblotianum } \\
\text { (Baill.) Drake }\end{array}$ & $\begin{array}{l}\text { Lasiobema } \\
\text { scandens (L.) } \\
\text { de Wit }\end{array}$ & $\begin{array}{l}\text { Lysiphyllum } \\
\text { cunninghamii } \\
\text { (Benth.) de Wit }\end{array}$ & $\begin{array}{l}\text { Phanera coccinea } \\
\text { Lour. }\end{array}$ & $\begin{array}{l}\text { Piliostigma } \\
\text { reticulatum } \\
\text { (DC.) Hochst. }\end{array}$ & $\begin{array}{l}\text { Schnella } \\
\text { macrostachya } \\
\text { Raddi }\end{array}$ & $\begin{array}{l}\text { Tylosema fassoglense } \\
\text { (Schweinf.) Torre } \\
\text { et Hillc. }\end{array}$ \\
\hline Habit & $\begin{array}{l}\text { Trees, shrubs } \\
\text { (rarely semi-scandent), } \\
\text { sometimes with } \\
\text { intrastipular spines, } \\
\text { rarely with thorns, } \\
\text { without tendrils }\end{array}$ & $\begin{array}{l}\text { Trees (unarmed, } \\
\text { up to } 18 \mathrm{~m} \text { tall) }\end{array}$ & $\begin{array}{l}\text { Mostly trees, } \\
\text { occasionally large } \\
\text { shrubs or climbers, } \\
\text { without tendrils }\end{array}$ & $\begin{array}{l}\text { Tendrilled } \\
\text { lianas, scandent } \\
\text { shrubs, without } \\
\text { intrastipular } \\
\text { spines or thorns }\end{array}$ & $\begin{array}{l}\text { Trees, semi- } \\
\text { scandent shrubs, } \\
\text { tendrilled lianas, } \\
\text { without intrastipular } \\
\text { spines or thorns }\end{array}$ & $\begin{array}{l}\text { Tendrilled lianas, } \\
\text { scandent shrubs, } \\
\text { rarely trees, without } \\
\text { intrastipular spines } \\
\text { or thorns }\end{array}$ & $\begin{array}{l}\text { Trees, shrubs, } \\
\text { without } \\
\text { tendrils }\end{array}$ & $\begin{array}{l}\text { Tendrilled lianas, } \\
\text { scandent shrubs, } \\
\text { without intrastipular } \\
\text { spines or thorns }\end{array}$ & $\begin{array}{l}\text { Trailing or climbing } \\
\text { herbs, lianas, without } \\
\text { intrastipular spines } \\
\text { or thorns }\end{array}$ \\
\hline Calyx & $\begin{array}{l}\text { Spathaceous, } \\
\text { splitting along } \\
\text { one side or } \\
\text { into } 2 \text { unequal } \\
\text { lobes }\end{array}$ & $\begin{array}{l}\text { Shortly lobed in } \\
\text { the upper part, } \\
\text { campanulate with } \\
\text { obtuse teeth }\end{array}$ & $\begin{array}{l}\text { Lobed, forming } \\
\text { a very long } \\
\text { hypanthium }\end{array}$ & $\begin{array}{l}\text { Lobed or } \\
\text { truncate }\end{array}$ & $\begin{array}{l}\text { Lobed or split, } \\
\text { broadly campanulate, } \\
\text { ribbed, rusty-velvety }\end{array}$ & $\begin{array}{l}\text { Lobed, forming } 4 \\
\text { or } 5 \text { approximately } \\
\text { equal lobes }\end{array}$ & $\begin{array}{l}\text { Lobed in the } \\
\text { upper part, } \\
\text { dentate }\end{array}$ & $\begin{array}{l}\text { Lobed or truncate, } \\
\text { five-veined or } \\
\text { inconspicuously } \\
\text { veined }\end{array}$ & $\begin{array}{l}\text { Lobed, forming a } \\
\text { short hypanthium }\end{array}$ \\
\hline $\begin{array}{l}\text { Fertile } \\
\text { stamen }\end{array}$ & $1-10$ & 10 & 10 & 3 & 10 & 3 , rarely 2 & 10 & 10 & 2 \\
\hline Distribution & Pantropics & Australia & $\begin{array}{l}\text { West and East } \\
\text { Africa, Malesia }\end{array}$ & Asia & $\begin{array}{l}\text { Australia, Southeast } \\
\text { Asia }\end{array}$ & $\begin{array}{l}\text { South and } \\
\text { Southeast Asia }\end{array}$ & $\begin{array}{l}\text { Africa, Asia, } \\
\text { Australia }\end{array}$ & Neotropics & Africa \\
\hline $\begin{array}{l}\text { Species } \\
\text { number }\end{array}$ & 154 & 1 & 6 & 22 & 8 & 92 & 3 & 49 & 5 \\
\hline
\end{tabular}




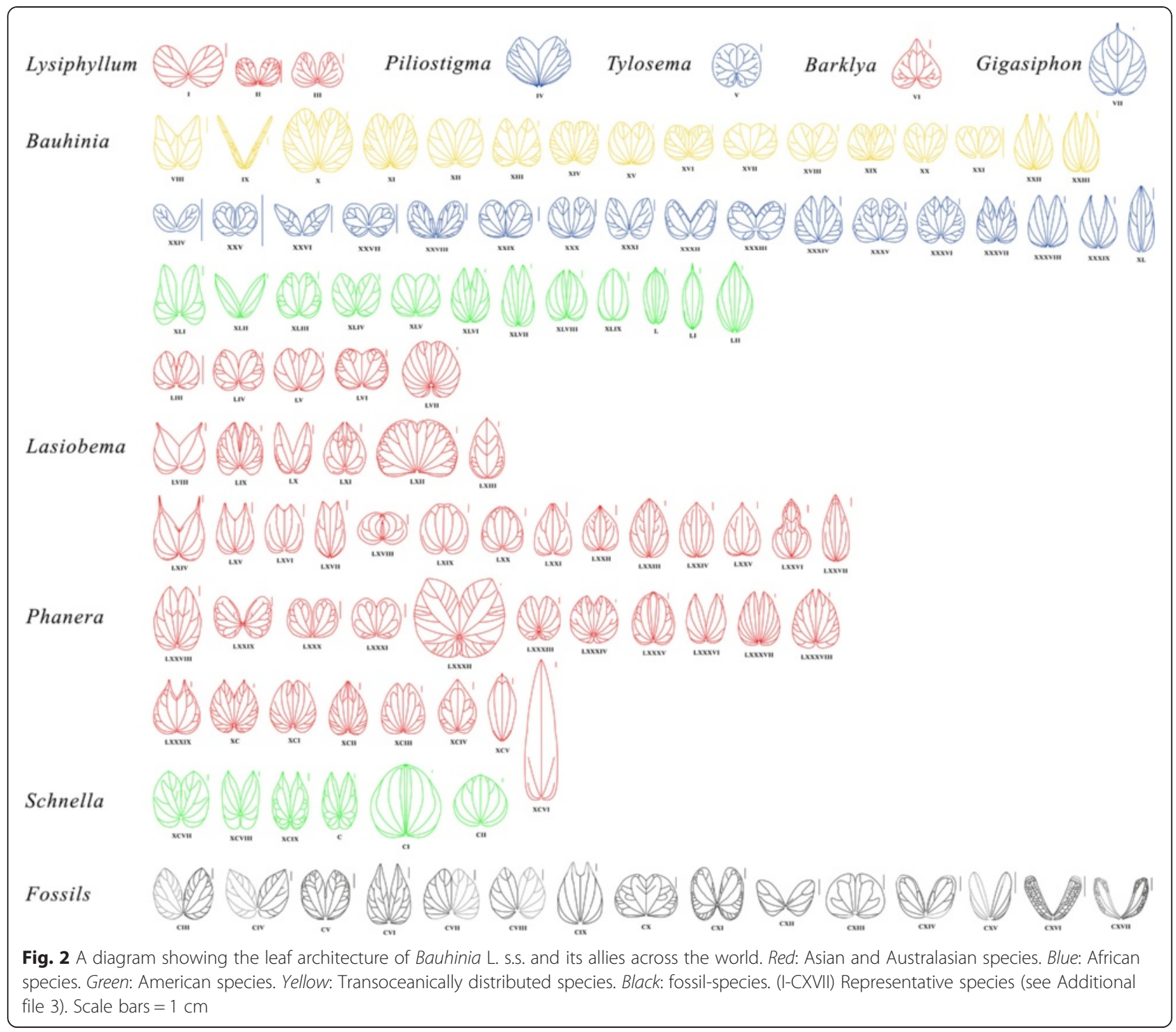

have been reported from the Cenozoic of Asia, Africa, North America, and South America [28-44] (Table 2), providing the opportunity to evaluate the early evolution, diversification, and biogeographic history of the orchid trees from an historical perspective.

In this article, we comprehensively investigate the leaf architecture of extant Bauhinia and its allies, describe two bilobate leafed fossil-species of Bauhinia from the middle Miocene Fotan Group of Fujian Province, southeastern China, and discuss their biogeographic implications.

\section{Methods}

\section{Macrofossils}

The fossil leaves investigated in this paper were collected from the Fotan Group at Lindai Village (lat. $24^{\circ} 12^{\prime} \mathrm{N}$, long.117 $53^{\circ} \mathrm{E}$ ) of Zhangpu County, Fujian Province, southeastern China (Fig. 3). Paleobotanical fieldwork was done in non-National Nature Reserves and nonprivate areas with the permission of the local government. The stratigraphy of the Fotan Group has previously been discussed in detail [45, 46]. Generally, it consists of basaltic rocks, arenaceous conglomerate rocks, sandstone and mudstone interbedded with lignite and diatomite. The outcrop at Lindai Village (i.e., sampling site) is composed of an upper layer of light-brown diatomite and an underlying layer of blue-gray mudstone (Fig. 3b, c). Both layers yield abundant plant fossils dominated by angiosperm leaves, but fruits are also present $[47,48]$. The fossils from the diatomite layer are commonly preserved as impressions with exquisite venation while those from the mudstone layer are often preserved as compressions with cuticle. The geological age of the Fotan flora in Zhangpu is considered the Langhian Stage 
Table 2 The leaf fossil record of Bauhinia previously reported and used in this study

\begin{tabular}{|c|c|c|c|c|c|}
\hline Fossil-species & Leaf size $^{a}$ & $\begin{array}{l}\text { Illustration and } \\
\text { notes }\end{array}$ & Locality & Geological age & Reference \\
\hline Bauhinia sp.1 & Ca. $2.2 \times 2.0 \mathrm{~cm}$ & Poorly illustrated & $\begin{array}{l}\text { Mahenge Site, } \\
\text { Singida Town, } \\
\text { Tanzania }\end{array}$ & Middle Eocene & {$[28]$} \\
\hline B. cheniae Q. Wang et al. & Ca. $2.0-6.0 \times 2.2-6.5 \mathrm{~cm}$ & Fig. 2CIII here & \multirow{3}{*}{$\begin{array}{l}\text { Ningming County, } \\
\text { Guangxi Zhuang } \\
\text { Autonomous Region, } \\
\text { China }\end{array}$} & \multirow{3}{*}{$\begin{array}{l}\text { Possibly late } \\
\text { Eocene or } \\
\text { Oligocene }\end{array}$} & \multirow[t]{3}{*}[29,30]{} \\
\hline B. larsenii D.X. Zhang et Y.F. Chen & Ca. $2.1-4.5 \times 1.8-4.8 \mathrm{~cm}$ & Fig. 2CV here & & & \\
\hline B. ningmingensis $\mathrm{Q}$. Wang et al. & Ca. $4.0-5.3 \times 4.0-5.2 \mathrm{~cm}$ & Fig. 2CIV here & & & \\
\hline $\begin{array}{l}\text { Bauhcis moranii Calvillo-Canadell } \\
\text { et Cevallos-Ferriz }\end{array}$ & $4.3-4.5 \times 5.8-6.4 \mathrm{~cm}$ & $\begin{array}{l}\text { Fig. } 2 C X \text {; attributed } \\
\text { to Bauhinia by } \\
\text { some authors }\end{array}$ & $\begin{array}{l}\text { Los Ahuehuetes, } \\
\text { Tepexi de Rodríguez, } \\
\text { Puebla, Mexico }\end{array}$ & Oligocene & [29-31] \\
\hline $\begin{array}{l}\text { Bauhinia krishnanunnii A.K. } \\
\text { Mathur et al. }\end{array}$ & $6.0 \times 5.0 \mathrm{~cm}$ & Fig. 2CIX here & $\begin{array}{l}\text { Dagshai Cantonment } \\
\text { and Daghota, Kalka-Shimla } \\
\text { Highway, Solan District, } \\
\text { Himachal Pradesh, India }\end{array}$ & Early Miocene & {$[32]$} \\
\hline $\begin{array}{l}\text { B. kachchhensis R.N. } \\
\text { Lakh. et Guleria }\end{array}$ & $\begin{array}{l}\text { Ca. } 6.2-8 \mathrm{~cm} \text { wide, at } \\
\text { least } 3.5-5 \mathrm{~cm} \text { long }\end{array}$ & $\begin{array}{l}\text { Incompletely } \\
\text { preserved }\end{array}$ & $\begin{array}{l}\text { Khari Nadi Bed, near } \\
\text { Goyela-Mokra; Thingdawl, } \\
\text { Mizoram; Kachchh, India }\end{array}$ & $\begin{array}{l}\text { Early-Middle } \\
\text { Miocene }\end{array}$ & [33-35] \\
\hline Bauhinia sp. 2 & $\begin{array}{l}7.0 \mathrm{~cm} \text { wide, at least } \\
3.0 \mathrm{~cm} \text { long }\end{array}$ & $\begin{array}{l}\text { Incompletely } \\
\text { preserved }\end{array}$ & $\begin{array}{l}\text { Mae Sot, Changwat } \\
\text { Tak, Thailand }\end{array}$ & $\begin{array}{l}\text { Late Early } \\
\text { Miocene-early } \\
\text { Middle Miocene }\end{array}$ & {$[36]$} \\
\hline B. ungulatoides sp. nov. & $7.5-9.5 \times 5.4-6.0 \mathrm{~cm}$ & Figs. 4 and 5 here & \multirow{2}{*}{$\begin{array}{l}\text { Lindai Village, Fotan } \\
\text { Town, Zhangpu } \\
\text { County, Zhangzhou City, } \\
\text { Fujian Province, } \\
\text { Southeast China }\end{array}$} & \multirow[t]{2}{*}{ Middle Miocene } & \multirow{2}{*}{$\begin{array}{l}{[37, \text { this }} \\
\text { study] }\end{array}$} \\
\hline $\begin{array}{l}\text { B. fotana F.M.B. Jacques } \\
\text { et al. emend. }\end{array}$ & Ca. $4.5-7.5 \times 4.0-6.0 \mathrm{~cm}$ & Fig. 6 here & & & \\
\hline $\begin{array}{l}\text { B. ramthiensis Antal et } \\
\text { N. Awasthi }\end{array}$ & Ca. $9.0 \times 8.6 \mathrm{~cm}$ & $\begin{array}{l}\text { Incompletely } \\
\text { preserved }\end{array}$ & $\begin{array}{l}\text { Right bank of upsteam } \\
\text { of Ramthi River near } \\
\text { Oodlabari, Darjeeling } \\
\text { District, West Bengal, } \\
\text { India }\end{array}$ & Middle Miocene & {$[38]$} \\
\hline $\begin{array}{l}\text { B. siwalika R.N. Lakh. et } \\
\text { N. Awasthi }\end{array}$ & $1.5-4.0 \times 2.0-6.0 \mathrm{~cm}$ & Fig. 2CXIII here & $\begin{array}{l}\text { Siwalik, Bhikhnathoree, } \\
\text { West Champaran District, } \\
\text { Bihar; Cherrapunji, } \\
\text { West Khasi Hills District, } \\
\text { Meghalaya, India }\end{array}$ & $\begin{array}{l}\text { Middle } \\
\text { Miocene-middle } \\
\text { Pleistocene }\end{array}$ & [39] \\
\hline B. ecuadorensis E.W. Berry & $5.25 \times 5.0 \mathrm{~cm}$ & Fig. 2CXI here & Loja Basin, Ecuador & Miocene & [40] \\
\hline $\begin{array}{l}\text { B. wenshanensis H.H. Meng et } \\
\text { Z.K. Zhou }\end{array}$ & Ca. $6.0-7.0 \times 3.0-4.0 \mathrm{~cm}$ & Fig. $2 \mathrm{CVI}$ here & $\begin{array}{l}\text { Dashidong Town, Wenshan } \\
\text { County, Southeast Yunnan } \\
\text { Province, China }\end{array}$ & Late Miocene & [41] \\
\hline $\begin{array}{l}\text { B. nepalensis N. Awasthi } \\
\text { et N. Prasad }\end{array}$ & $4.5-7.5 \times 5.6-11.4 \mathrm{~cm}$ & Fig. 2CVII here & $\begin{array}{l}\text { Surai Khola beds, near } \\
\text { Surai Khola bridge, } \\
\text { Surai Khola, Nepal }\end{array}$ & $\begin{array}{l}\text { Late Miocene- } \\
\text { late Pleistocene }\end{array}$ & {$[42]$} \\
\hline B. waylandii R.W. Chaney & $2.5 \times 2.5 \mathrm{~cm}$ & Fig. 2CXII here & $\begin{array}{l}\text { Busano, Bugishu } \\
\text { District, Eastern } \\
\text { Province, Uganda }\end{array}$ & Pliocene & [43] \\
\hline Bauhinia sp. 3 & $5.5 \times 7.0 \mathrm{~cm}$ & Fig. 2CVIII here & $\begin{array}{l}\text { Mahuadanr Valley, } \\
\text { Palamu District, } \\
\text { Bihar, India }\end{array}$ & Neogene & [44] \\
\hline
\end{tabular}

${ }^{\mathrm{a}}$ As far as the bifoliolate-leafed species are concerned, each leaf is viewed twice as wide as one leaflet

of middle Miocene [49] on the basis of an Argon-Argon $\left({ }^{40} \mathrm{Ar} /{ }^{39} \mathrm{Ar}\right)$ radiometric dating $(14.8 \pm 0.6 \mathrm{Ma})$ of the basaltic rocks underlying the fossil-bearing layers (Fig. 3c).

The studied fossil leaves were examined and photographed using digital cameras (Panasonic DMC-FZ30 and Nikon D90). The cuticles were macerated using
Schulze's solution followed by diluted Ammonia (for a detailed procedure see [50]), and then mounted on slides, examined and photographed on a Zeiss AxioScope A1 microscope. Both the figured macrofossil specimens and cuticle slides (prefixed "PB") are deposited at Nanjing Institute of Geology and Palaeontology, Chinese Academy of Sciences, Nanjing, P.R. China. 


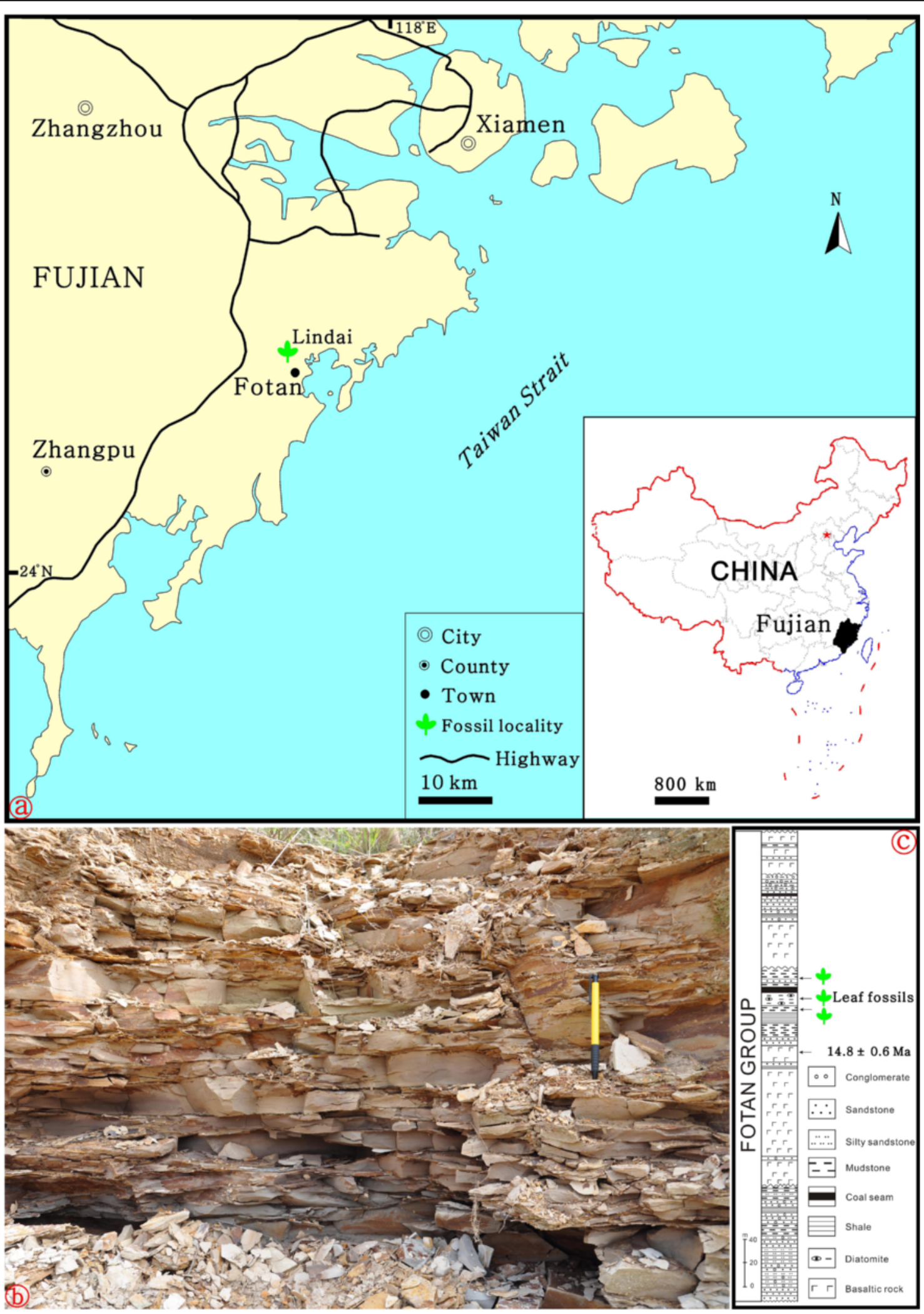

Fig. 3 A diagram showing the fossil locality and stratigraphy. The maps and images are made and completed by the present authors. a A map indicating the fossil location. b The sampling site. c A stratigraphical column of the Fotan Group 
In addition, we examined the previously reported $\mathrm{Bau}$ hinia leaf fossils from the Oligocene Ningming Formation of Guangxi, South China [29, 30] and the Neogene of India and Nepal [38, 39, 42, 44]. The specimens are housed at Natural History Museum of Guangxi, Nanning (NHMG) and Birbal Sahni Institute of Palaeobotany, Lucknow (BSIP) (see Additional file 3).

\section{Herbaria}

The exsiccatae used in this study are from the following Herbaria: Harvard University, Cambridge (A), The Natural History Museum, London (BM), National Botanic Garden of Belgium, Meise (BR), Queensland Herbarium, Brisbane (BRI), Royal Botanic Garden Edinburgh, Edinburgh (E), Field Museum of Natural History, Chicago (F), Centro Studi Erbario Tropicale Università degli Studi di Firenze, Firenze (FT), Conservatoire et Jardin Botaniques de la Ville de Genève, Genève (G), Royal Botanic Gardens, Kew (K), National Herbarium Nederland, Leiden University Branch, Leiden (L), Botanische Staatssammlung München, München (M), Real Jardín Botánico, Madrid (MA), National Herbarium of Victoria, Melbourne (MEL), Missouri Botanical Garden, Missouri (MO), The New York Botanical Garden, Bronx (NY), Muséum National d'Histoire Naturelle, Paris $(\mathrm{P})$, The Chinese National Herbarium, Beijing (PE), the Swedish Museum of Natural History, Stockholm (S), Trinity College, Dublin (TCD), Smithsonian Institution, Washington (US), and Wageningen University, Wageningen (WAG) (see Additional file 3).

\section{Online databases}

(1) ILDIS (International Legume Database \& Information Service) [51]. The species and distribution of Bauhinia and its allies have been compiled by ILDIS, with special reference to some recently published taxonomic articles (Table 1; see Additional file 1). (2) eFloras.org [52]. Morphological descriptions and illustrations of Bauhinia and its allies concerned here were checked. (3) Chinese Virtual Herbarium (CVH) [53]. Online images of herbarium specimens of Bauhinia and its allies were browsed. (4) Index Herbarium [54]. The standardized Herbarium codes were adopted. (5) The International Plant Names Index [55]. The standardized abbreviations for authors of plant-names and journal titles in References were consulted and adopted in this paper.

\section{Terminology}

The gross morphology, venation, and cuticle of modern and fossil leaves were described on the basis of the standard terminology $[56,57]$. The morphological interpretation and terms specifically for leaves of the Cercideae follow the literature [24, 27, 30]. Time calibrations and geological terms referred to the latest International Chronostratigraphic Chart [58].

\section{Figures}

A simplified diagram (Fig. 1) showing the phylogenetic relationships and divergence times of Bauhinia and its allies was redrawn from literature $[12,13]$. The diagram of the locality and strata (Fig. 3) as well as line-drawings of both modern and fossil leaves (Figs. 2, 4 and 6) were drawn using CorelDRAW 12.0 program, and photographs of the sampling site and specimens were combined into figures using CorelDRAW 12.0 program (Figs. 2, 3, 4, 5 and 6).

\section{Leaf morphological analyses}

Leaf morphological variables are measured and calculated using CorelDRAW 12.0 on the basis of leaf images (Fig. 2) from illustrated species, including the length-towidth/2 ratio, dissection index, and sinus (see Additional file 4). The dissection index (DI) is the ratio of an outline's perimeter to the square root of its area [59-61], i.e., $\mathrm{DI}=$ Perimeter $/[2 \mathrm{sqrt}(\pi \times$ Area $)]$, which is a standardized metric to determine shape complexity, especially regarding the complex degree of bilobate leaves studied here.

\section{Results}

\section{Leaf morphology of Bauhinia and its allies}

The leaf architecture of 100 representatives of the Bauhiniinae including 15 fossil species is illustrated here (Fig. 2I-CXVII; see Additional file 2 for each species name), accounting for ca. $1 / 3$ of the species in the subtribe. Leaves of Bauhiniinae (Table 1; see Additional file 1) are generally characterized by unifoliolate, bilobate and bifoliolate types, and the bilobate type is the commonest (Fig. 2). By observing and analyzing 10 characters, i.e., length-to-width $/ 2$ ratio, dissection index (Perimeter/[2sqrt $(\pi \times$ Area $)])$, apex, base, lobation, sinus, texture, primary veins (1), secondary veins (2), and epidermal anatomy [62-69], we compared the leaf architecture and morphological complexity of Bauhinia and its allies (Table 3; see Additional file 4).

\section{Systematics}

Family Leguminosae Juss.

Subfamily Caesalpinioideae DC.

Tribe Cercideae Bronn

Subtribe Bauhiniinae (Benth.) Walp.

Genus Bauhinia L. s.s.

Type Bauhinia divaricata L.

\section{Fossil species}

Two fossil-species of Bauhinia are described as follows. All the voucher specimens were collected from 

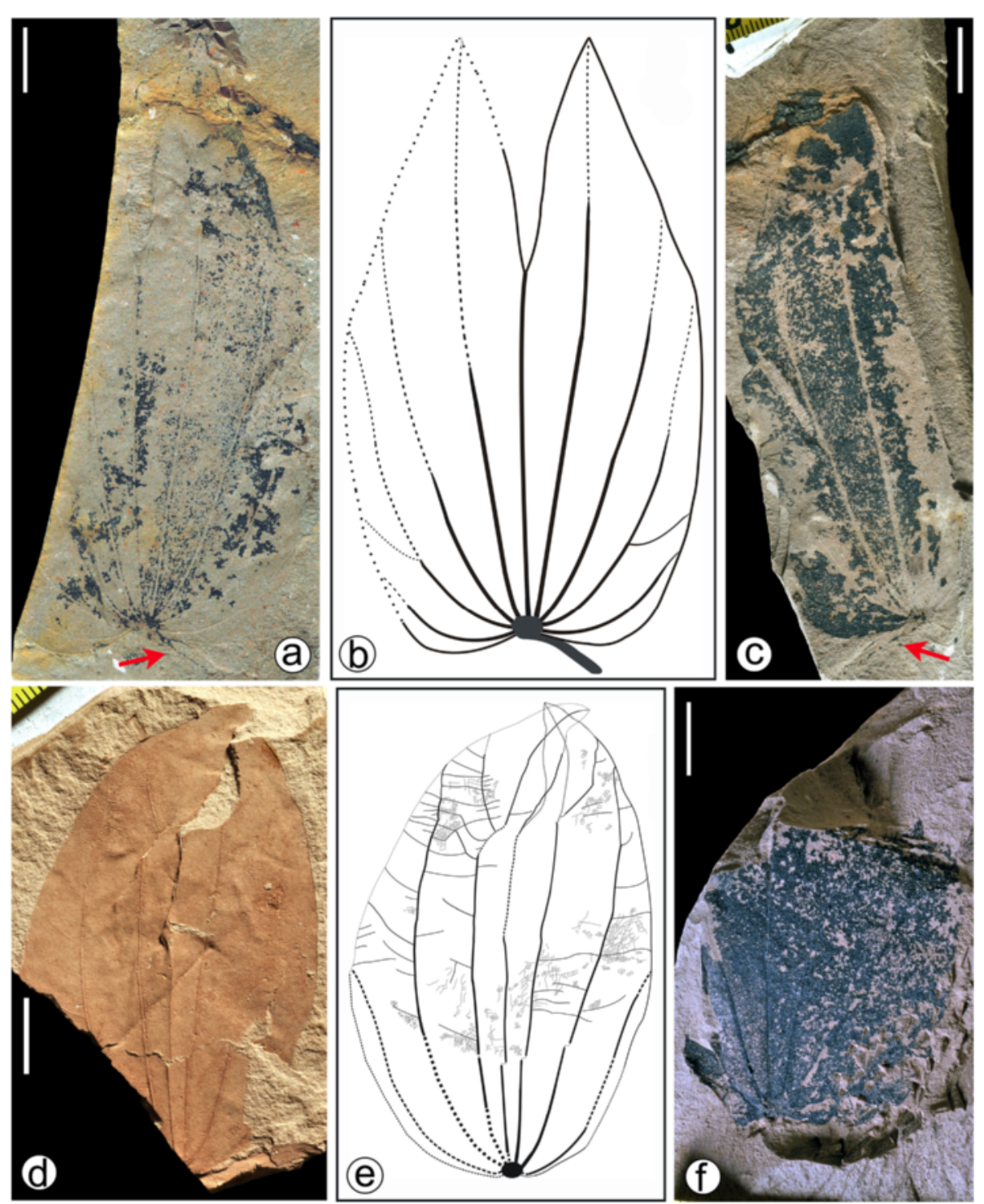

Fig. 4 Leaf morphology of Bauhinia ungulatoides sp. nov. from the middle Miocene of Fujian Province, southeastern China. a-c Holotype, PB21584 a, b and its line drawing, indicating extremely ascending primary veins $\left(1^{\circ}\right)$ and acute apices. Red arrows refer to a partially preserved petiole. d-e PB21585, showing extremely ascending $1^{\circ}$, but slightly deformed due to preservational crushing. f PB21586, indicating a partially preserved leaf with a base and similar $1^{\circ}$ to those in $(\mathbf{a}-\mathbf{c})$. Scale bars $=1 \mathrm{~cm}$

the same locality and stratigraphy and are deposited at the same institute.

\section{Type locality}

Lindai Village, Zhangpu County, Zhangzhou City, Fujian Province, P. R. China (Fig. 3a).

\section{Stratigraphic horizon and age}

The middle part of the Fotan Group, Langhian Stage (middle Miocene) (Fig. 3b, c).

\section{Repository}

Nanjing Institute of Geology and Palaeontology, Chinese Academy of Sciences, Nanjing, P.R. China.

Bauhinia ungulatoides Y.X.Lin, W.O.Wong, G.L.Shi, S.Shen et Z.Y.Li, sp. nov. (Figs. 4 and 5).

\section{Etymology}

The specific epithet is derived from the Latin "ungulatus" (hoof-shaped) suffixed by "oides" (resembling), implying the striking similarities between leaves of studied fossils and extant Bauhinia ungulata L. (Fig. 2XXIII). 

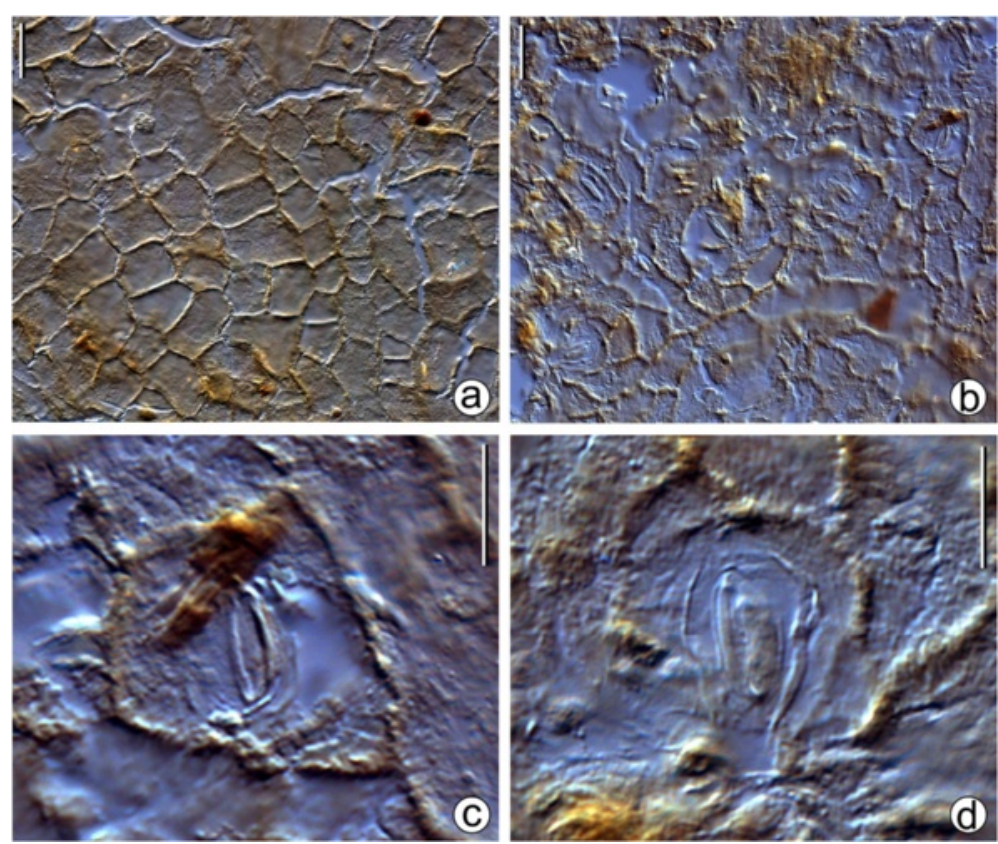

Fig. 5 Leaf micromorphology of Bauhinia ungulatoides sp. nov. from the middle Miocene of Fujian Province, southeastern China. The cuticles from the holotype, PB21584 c, d. a Adaxial cuticle showing the morphology of epidermal cells. b Abaxial cuticle showing the orientation of stomata. Scale bars $=20 \mu \mathrm{m}$. $\mathbf{c}$-d showing an enlarged paracytic stomatal complex from (b). Scale bars $=10 \mu \mathrm{m}$

\section{Holotype}

PB21584a, b, c, d (Fig. 4a, c; Fig. 5a, b) (designated here. A gathering with part and counterpart specimens, including slides of leaf cuticles).

\section{Paratypes}

PB21585 (Fig. 4d), PB21586 (Fig. 4f) (designated here).

\section{Diagnosis}

Lamina ovate-elliptical or elliptical in outline, shallowly to moderately bilobate, with pulvinate petiole and untoothed margin. Laminar base slightly or shallowly cordate, lobe apex acute. Primary venation basal actinodromous with 7-9 basal veins. Midvein terminated at the bottom of a narrow sinus. Lateral primaries straight or curved, and the innermost pairs reaching the lobe apex and outer pairs approaching to the laminar margin. Secondary veins craspedodromous. Intersecondary veins present. Tertiary veins opposite and alternate percurrent. Quaternary veins forming irregular polygons. Areolation well developed. Freely ending veinlets unbranched. Marginal ultimate veins absent; leaves hypostomatic. Epidermal cells on both surfaces, similarly quadrangular or pentagonal, with straight or slightly curved anticlinal walls. Stomatal complexes paracytic, randomly oriented.

\section{Description}

The leaf attachment is petiolate. Petioles are partially preserved, at least $1.5 \mathrm{~cm}$ long, with a tiny, semicircular upper pulvinus impression connecting the laminar base (Fig. 4a-c). Laminae are bilobate, ovate-elliptical or elliptical in outline (Fig. 4a-e), ca. 7.5-9.5 cm long and 5.4$6.0 \mathrm{~cm}$ wide. The apex is bifid to ca. $1 / 3-2 / 5$ of laminar length, with a reflex apex angle at ca. $20^{\circ}-30^{\circ}$ (Fig. $4 \mathrm{a}, \mathrm{b}$, $\mathrm{d}, \mathrm{e})$. Two lobes are symmetrical or slightly asymmetrical. Lobe apices are acute. Laminar bases are slightly or shallowly cordate (Fig. 4a-f). The margin is entire. The texture appears coriaceous. Primary venation is basal actinodromous with 7-9 basal veins. The midvein is straight, moderate in thickness, terminated at the bottom of the sinus. Lateral primaries are straight or curved, extremely ascending and rarely branched, and the innermost pairs reaching the lobe apex and outer pairs approaching to the laminar margin (Fig. 4a-f). Secondary veins are less prominent, craspedodromous, diverging at ca. $40^{\circ}-80^{\circ}$ from the innermost and outmost lateral primaries and approaching to the laminar margin (Fig. 4a, b, d, e). Intersecondary veins are approximately parallel to neighboring secondary veins, radiating out about $1 / 3-1 / 2$ of distance from the primaries to laminar margin. Tertiary veins are opposite and alternate percurrent, slightly curved to sinuous, connecting the neighboring primary veins or between the primary veins and the secondary veins (or the margin). Quaternary veins are linked with other higher veins, forming irregular polygons (Fig. 4d, e). The areolation is well developed. Freely ending veinlets are unbranched. Marginal ultimate veins are absent. 


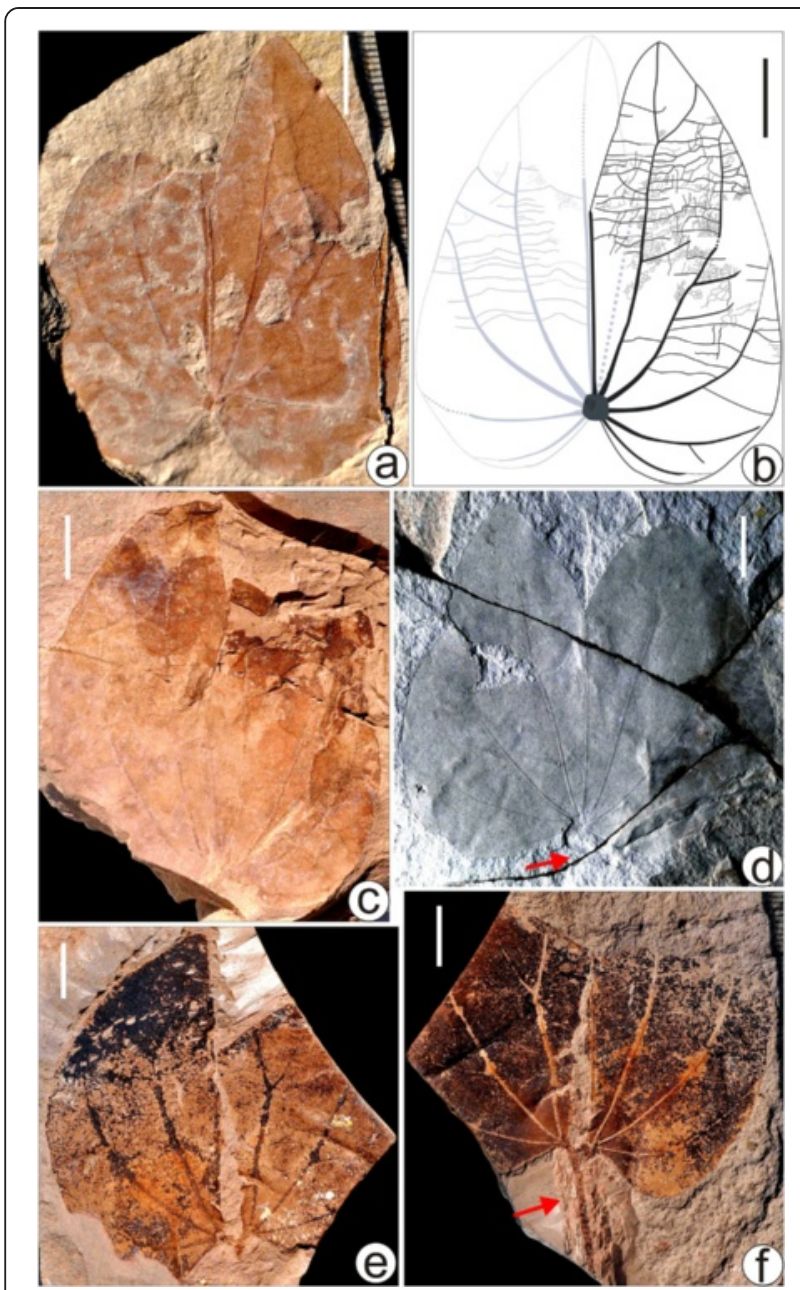

Fig. 6 Leaf morphology of Bauhinia fotana from the middle Miocene of Fujian Province, southeastern China. a-b Epitype, PB21579 and its line-drawing, showing the detailed leaf architecture. Note that this leaf was torn along the midvein and then became partially overlapped of two lobes after a twist during the process of fossilization. c PB21580, showing basal actinodromous primary veins $\left(1^{\circ}\right)$. Note that the apical parts of the leaf were deformed. d Holotype, PB21577, indicating a relatively complete leaf with stout, basal actinodromous $1^{\circ}$. e-f PB21581a, b, showing the part and counterpart specimens of a leaf. Note that this leaf was torn near the midvein, and the right lobe was partially folded. Red arrows in $(\mathbf{d}, \mathbf{f})$ refer to a partially preserved petiole. Scale bars $=1 \mathrm{~cm}$

Leaves are hypostomatic. The adaxial cuticle consists of isodiametric to slightly elongated epidermal cells. These cells are usually quadrangular or pentagonal, rarely hexagonal or heptagonal, with straight to slightly curved anticlinal walls and smooth periclinal walls (Fig. 5a). Epidermal cells in abaxial cuticles are similar in form and size to those in adaxial cuticles. Stomata are evenly distributed in the nonvenous region of abaxial cuticles and randomly oriented (Fig. 5b). Stomatal complexes are paracytic, commonly asymmetrical, ovate, elliptical to oblong in outline. Subsidiary cells are crescent or irregularly shaped. Guard cells are not sunken (Fig. 5c, d). Trichomes or trichome bases are not observed.

\section{Comparisons}

The bilobate leaves described here are obviously different from five small genera, i.e., Lysiphyllum, Piliostigma, Tylosema, Barklya and Gigasiphon (Fig. 2I-VII; Table 3). Leaves of extant Tylosema, Barklya and Gigasiphon are unlobed or only very slightly bilobate; Lysiphyllum are bifoliolate. Piliostigma has bilobate leaves like our fossil leaves, but differs in having more basal veins (11) and bigger reflex apex angle $\left(80^{\circ}-90^{\circ}\right)$. Following comparison with extant Bauhinia, Lasiobema, Phanera and Schnella (Fig. 2VIII-CII; Table 3), the present leaf fossils are attribute to Bauhinia in the light of character combinations such as very similar leaf architecture and dissection index. Leaves of Schnella have cordate, even auriculate bases (Fig. 2XCVII-C). In Phanera, leaves are usually broader than [lower in $\mathrm{L} /(\mathrm{W} / 2)$ ratio] than B. ungulatoides (Table 3; see Additional file 4), and the widest part is near the base (Fig. 2LXXXVII-XCIII). Bauhinia ungulatoides are similar to Phanera coccinea Lour. (Fig. 2LXXVIII), but are more shallowly bilobate. It can also be easily distinguished from the bilobate leaves of Lasiobema by reflex apex angles at ca. $20^{\circ}-30^{\circ}$. The reflex apex angles of leaves in Lasiobema are either very wide $\left(>40^{\circ}\right.$ ) (Fig. 2LVIII, LX, LXIV-LXVII) or extremely narrow $\left(<10^{\circ}\right)$ sinus (Fig. 2LIX, LXI, LXXI, LXXII) (see Additional file 4). Bauhinia ungulatoides is characterized by shallowly cordate bases and acute apices on each lobe. It is more or less distinguishable from the bilobate leaves of Bauhinia's allies in Bauhiniinae (Table 3). Although it is possible that these similarities are result of convergent evolution it is worth noting that Bauhinia ungulatoides is most similar to two South American species, i.e., B. ungulata (Fig. 2XXIII) and B. forficata Link $[26,63]$ (Fig. 2XXII), among the investigated extant species. They all bear extremely ascending and rarely branched lateral primary veins. However, since the reproductive organs of $B$. ungulatoides are unknown, it is more appropriate to assign it to a new fossil-species rather than to any extant species. Regarding fossil-species (Table 2), B. ungulatoides is similar to B. wenshanensis H.H. Meng et Z.K. Zhou from the late Miocene of Yunnan, southwestern China [41] (Fig. 2CVI), but the latter bears more secondary veins.

Bauhinia fotana F.M.B.Jacques, G.L.Shi et Z.K.Zhou emend. Y.X.Lin, W.O.Wong, G.L.Shi, S.Shen et Z.Y.Li (Fig. 6).

Bauhinia fotana F.M.B. Jacques, G.L. Shi et Z.K. Zhou in Jacques et al., Rev. Palaeobot. Palynol. 216: 78, Fig. 3a, pl. 1, Figs. 1, 2, 2015. 
Table 3 Leaf morphological comparisons between Bauhinia and its allies (Fig. 2; see Additional file 4)

\begin{tabular}{|c|c|c|c|c|c|c|}
\hline Taxon names & $\begin{array}{l}\text { Bauhinia L. S.s. outside } \\
\text { America }\end{array}$ & Bauhinia L. s.s. in America & $\begin{array}{l}\text { Bauhinia ungulatoides Y.X. } \\
\text { Lin et al. }\end{array}$ & $\begin{array}{l}\text { Bauhinia fotana F.M.B. } \\
\text { Jacques et al. }\end{array}$ & Barklya F. Muell. & Gigasiphon Drake \\
\hline Length/(Width/2) & 2.191 & 3.306 & 3.439 & 2.329 & 2.101 & 2.572 \\
\hline $\begin{array}{l}\text { Dissection index } \\
\text { (Perimeter/[2sqrt } \\
(\pi \times \text { Area)]) }\end{array}$ & 1.350 & 1.320 & 1.388 & 1.322 & 1.183 & 1.181 \\
\hline Apex & Obtuse, acuminate or acute & $\begin{array}{l}\text { Acuminate or acute, rarely } \\
\text { obtuse }\end{array}$ & Acute & Acute or slightly obtuse & Acuminate & $\begin{array}{l}\text { Acuminate, with a } \\
\text { drip tip }\end{array}$ \\
\hline Base & $\begin{array}{l}\text { Cuneate, truncate, or Slightly } \\
\text { to deeply cordate }\end{array}$ & $\begin{array}{l}\text { Cuneate, truncate or slightly } \\
\text { cordate, rarely deeply cordate }\end{array}$ & Slightly or shallowly cordate & $\begin{array}{l}\text { Moderately to deeply } \\
\text { cordate }\end{array}$ & Deeply cordate & Slightly cordate \\
\hline Lobation & $\begin{array}{l}\text { Bilobate or bifoliolate, rarely } \\
\text { unifoliolate }\end{array}$ & $\begin{array}{l}\text { Bilobate or unifoliolate, rarely } \\
\text { bifoliolate }\end{array}$ & Bilobate & Bilobate & Unifoliolate & Unifoliolate \\
\hline Texture & Chartaceous to coriaceous & Mainly coriaceous & Coriaceous & Chartaceous & Chartaceous & Coriaceous \\
\hline Sinus & No or $<120^{\circ}$ & No or $<80^{\circ}$ & $20^{\circ}-30^{\circ}$ & $30^{\circ}-45^{\circ}$ & No & No \\
\hline \multirow[t]{2}{*}{$1^{\circ}$ veins } & $\begin{array}{l}\text { Actinodromous or } \\
\text { acrodromous }\end{array}$ & $\begin{array}{l}\text { Actinodromous or } \\
\text { acrodromous }\end{array}$ & Actinodromous & Actinodromous & Actinodromous & Actinodromous \\
\hline & $\begin{array}{l}5-13 \text { in number Not } \\
\text { branched to frequently } \\
\text { branched }\end{array}$ & $\begin{array}{l}\text { 5-9 Not branched or less } \\
\text { branched, frequently } \\
\text { branched rarely }\end{array}$ & 7-9 Less branched & 9-11 Branched & $\begin{array}{l}7 \text { Frequently } \\
\text { branched }\end{array}$ & 7 Branched \\
\hline $2^{\circ}$ veins & $\begin{array}{l}\text { Craspedodromous, } \\
\text { eucamptodromous or } \\
\text { brochidodromous }\end{array}$ & $\begin{array}{l}\text { Craspedodromous, } \\
\text { eucamptodromous, rarely } \\
\text { brochidodromous }\end{array}$ & Craspedodromous & Eucamptodromous & Cladodromous & Eucamptodromous \\
\hline $\begin{array}{l}\text { Epidermal anatomy } \\
\text { ([7, 17-19, 21, 22, 62-69], } \\
\text { this paper) }\end{array}$ & $\begin{array}{l}\text { Epidermal walls straight, } \\
\text { wavy or sinuate; stomata } \\
\text { paracytic, anomocytic, } \\
\text { anisocytic or tetracytic; } \\
\text { trichomes multicellular, } \\
\text { uniseriate, unicellular or no; } \\
\text { glands present or not }\end{array}$ & $\begin{array}{l}\text { Epidermal walls straight or } \\
\text { wavy; stomata anomocytic or } \\
\text { paracytic, trichomes } \\
\text { uniseriate or multiseriate, } \\
\text { glandular; glands present or } \\
\text { not }\end{array}$ & $\begin{array}{l}\text { Epidermal walls straight or } \\
\text { slightly curved; stomata } \\
\text { paracytic; no trichome; } \\
\text { no gland }\end{array}$ & Not preserved & $\begin{array}{l}\text { Trichomes sometimes } \\
\text { sparse, caducous; } \\
\text { minute intrastipular } \\
\text { trichomes }\end{array}$ & $\begin{array}{l}\text { Subglabrous or } \\
\text { almost glabrous, } \\
\text { with minute } \\
\text { trichomes } \\
\text { on the veins }\end{array}$ \\
\hline
\end{tabular}


Table 3 Leaf morphological comparisons between Bauhinia and its allies (Fig. 2; see Additional file 4) (Continued)

\begin{tabular}{|c|c|c|c|c|c|c|}
\hline Taxon names & Lasiobema (Korth.) Miq. & $\begin{array}{l}\text { Lysiphyllum (Benth.) } \\
\text { de Wit }\end{array}$ & Phanera Lour. & Piliostigma Hochst. & Schnella Raddi & $\begin{array}{l}\text { Tylosema (Schweinf.) } \\
\text { Torre et Hillc. }\end{array}$ \\
\hline Length/(Width/2) & 2.798 & 1.422 & 2.750 & 1.702 & 2.612 & 1.761 \\
\hline $\begin{array}{l}\text { Dissection index } \\
\text { (Perimeter/[2sqrt } \\
(\pi \times \text { Area)]) }\end{array}$ & 1.232 & 1.447 & 1.313 & 1.121 & 1.490 & 1.198 \\
\hline Apex & $\begin{array}{l}\text { Acuminate or acute, rarely } \\
\text { obtuse }\end{array}$ & Obtuse or rounded & $\begin{array}{l}\text { Obtuse, acuminate } \\
\text { or acute }\end{array}$ & Obtuse & Acuminate or acute & Rounded \\
\hline Base & $\begin{array}{l}\text { Slightly to deeply cordate or } \\
\text { cuneate, rarely truncate }\end{array}$ & $\begin{array}{l}\text { Slightly to deeply } \\
\text { cordate }\end{array}$ & $\begin{array}{l}\text { Slightly to deeply cordate, } \\
\text { raely cuneate }\end{array}$ & Cuneate & Slightly to deeply cordate & Moderately cordate \\
\hline Lobation & Bilobate or unifoliolate & Bifoliolate & $\begin{array}{l}\text { Bilobate, bifoliolate or } \\
\text { unifoliolate }\end{array}$ & Bilobate & Bilobate, rarely bifoliolate & Unifoliolate \\
\hline Texture & Mainly chartaceous & Chartaceous & Chartaceous to coriaceous & Mainly coriaceous & Mainly coriaceous & Chartaceous \\
\hline Sinus & No or $<130^{\circ}$ & $15^{\circ}-30^{\circ}$ & No or $<75^{\circ}$ & $80^{\circ}-90^{\circ}$ & No or $<25^{\circ}$ & $70^{\circ}-80^{\circ}$ \\
\hline \multirow[t]{2}{*}{$1^{\circ}$ veins } & Actinodromous or acrodromous & Actinodromous & $\begin{array}{l}\text { Actinodromous or } \\
\text { acrodromous }\end{array}$ & Actinodromous & $\begin{array}{l}\text { Actinodromous or } \\
\text { acrodromous }\end{array}$ & Actinodromous \\
\hline & $\begin{array}{l}\text { 5-9 Not branched to frequently } \\
\text { branched }\end{array}$ & $\begin{array}{l}8-10 \text { Frequently } \\
\text { branched }\end{array}$ & $\begin{array}{l}5-13 \text { Not branched to } \\
\text { frequently branched }\end{array}$ & 11 Frequently branched & $\begin{array}{l}\text { 7-11 Not branched to } \\
\text { frequently branched }\end{array}$ & 9 Frequently branched \\
\hline $2^{\circ}$ veins & $\begin{array}{l}\text { Brochidodromous or } \\
\text { eucamptodromous }\end{array}$ & $\begin{array}{l}\text { Craspedodromous or } \\
\text { eucamptodromous }\end{array}$ & $\begin{array}{l}\text { Brochidodromous } \\
\text { craspedodromous, } 1 \text { or } \\
\text { eucamptodromous }\end{array}$ & $\begin{array}{l}\text { Simple } \\
\text { brochidodromous }\end{array}$ & $\begin{array}{l}\text { Craspedodromous, } \\
\text { eucamptodromous or } \\
\text { brochidodromous }\end{array}$ & Cladodromous \\
\hline $\begin{array}{l}\text { Epidermal anatomy } \\
\text { ([7, 17-19, 21, 22, 62-69], } \\
\text { this paper) }\end{array}$ & $\begin{array}{l}\text { Epidermal walls straight; stomata } \\
\text { tetracytic; no trichome }\end{array}$ & $\begin{array}{l}\text { Epidermal walls } \\
\text { wavy or sinuate; } \\
\text { stomata tetracytic; } \\
\text { no trichome }\end{array}$ & $\begin{array}{l}\text { Epidermal walls wavy or sinuate; } \\
\text { stomata anisocytic, tetracytic, } \\
\text { anomocytic or paracytic; } \\
\text { trichomes on both surfaces; } \\
\text { no gland }\end{array}$ & $\begin{array}{l}\text { Epidermal walls straight; } \\
\text { stomata anomocytic or } \\
\text { anisocytic; trichomes } \\
\text { multicellular, unicellular, } \\
\text { uniseriate and hooked; } \\
\text { no gland }\end{array}$ & $\begin{array}{l}\text { Epidermal walls undulate or } \\
\text { sinuate; trichomes glandular, } \\
\text { multicellular, uniseriate; } \\
\text { no gland }\end{array}$ & $\begin{array}{l}\text { Trichomes linear, } \\
\text { canaliculate, with } \\
\text { a ring and conical base } \\
\text { or not; no gland }\end{array}$ \\
\hline
\end{tabular}




\section{Holotype}

PB21577 (Fig. 6d herein) (first designated and illustrated by Jacques et al. [37]).

\section{Epitype}

PB21579 (Fig. 6a, b) (An epitype is selected and designated here under Article 9.8 of the ICN (Melbourne Code) [70] to display the detailed leaf architecture that the holotype lacks).

Paratype (first designated and illustrated by Jacques et al. [37]).

PB21578.

\section{Other specimens examined here}

PB21580 (Fig. 6c), PB21581a, b (Fig. 6e, f), PB21582, and PB21583.

\section{Emended description}

The leaf attachment is petiolate. Petioles are partially preserved, at least ca. 1/2 of laminar length, with a tiny, semicircular upper pulvinus impression connecting the laminar base (Fig. 6a, b, e, f). Laminae are bilobate, broadly ovate to suborbicular in outline (Fig. 6a-f), ca. $4.5-7.5 \mathrm{~cm}$ long and $4.0-6.0 \mathrm{~cm}$ wide. The apex is bifid to ca. 1/3 of laminar length, with a reflex apex angle at ca. $30^{\circ}-45^{\circ}$ (Fig. 6b, d). Two lobes are symmetrical or slightly asymmetrical. Lobe apices are acute or slightly obtuse. Laminar bases are moderately to deeply cordate (Fig. 6a-f). The margin is entire. The texture appears chartaceous. Primary venation is basal actinodromous with 9-11 basal veins. The midvein is stout in thickness, terminated at the bottom of the sinus. The outmost pairs are weaker than the midvein and inner pairs. Lateral primaries are curved, branched or unbranched, and the innermost pairs reach the lobe apex and outer pairs approaching to the laminar margin (Fig. 6a-f). Secondary veins are eucamptodromous, diverging at ca. $45^{\circ}-80^{\circ}$ from the innermost and outmost lateral primary veins and approaching to the laminar margin (Fig. 6a-b). Tertiary veins are opposite and alternate percurrent, mostly sinuous and convex, rarely straight, connecting the neighboring primary veins or between the primary veins and the secondary veins (or the margin), as well as forming agrophic veins to the margin at the laminar base (Fig. 6a-b). Quaternary veins are linked with other higher veins, forming irregular polygons (Fig. $6 \mathrm{~b}$ ). The areolation is well developed. Freely ending veinlets are unbranched. Marginal ultimate veins are absent. Cuticles are unavailable.

\section{Comparisons}

Bauhinia fotana was originally described on the basis of two fossil leaves [37], but the initial description is very simple without characters of high order veins known.
Here, we emended it based upon its types and newly collected specimens from the same locality. Its leaves are broader [smaller in $\mathrm{L} /(\mathrm{W} / 2)$ ratio] than Schnella (Fig. 2XCVIII-C) and most Phanera species (Fig. 2LXXVIII, LXXXVI-LXXXVIII) (Table 3, see Additional file 4). Bauhinia fotana is somewhat similar to Phanera ornata (Kurz) Thoth. (Fig. 2XC), but bears more deeply bilobate leaves with much less secondary veins. It is different from Lasiobema, which usually has an obvious caudate apex (Fig. 2LVIII, LXIV, LXV). Except for the size $(4.5-7.5 \times 4.0-6.0 \mathrm{~cm}), B$. fotana shows great similarities with the extant $B$. acuminata L. (9$12 \times 8-12.5 \mathrm{~cm}$ ) (Fig. 2XIII) in bearing broadly ovate or suborbicular bilobate leaves with an acute apex, a moderately to deeply cordate base as well as similar venation. Among the fossil species (Table 2), B. fotana closely resembles Bauhinia sp. 3 (Fig. 2CVIII) from the Neogene of India [44], but the latter bears weak primary veins and larger $\mathrm{L} /(\mathrm{W} / 2)$ ratio of leaves.

\section{Discussions}

The pantropical genus Bauhinia and its allies have similarly bilobate, bifoliolate, or unifoliolate leaves. They along with the northern temperate to subtropical genus Cercis L. constitute the tribe Cercideae as sister to the remaining legumes in the molecular phylogenetic trees [1-5, 10-13] (Fig. 1). Recently, strictly east-to-west vicariances for the biogeographic evolution of Cercis and Bauhinia have been suggested through molecular analyses $[41,71]$. The earliest diverging clades in the Bauhiniinae were inferred to make their debut most possibly in Asia during the middle Paleocene (ca. 62.7 Ma) [41]. The fossil record of Cercis and Bauhinia can provide key points of reference for deciphering the early evolution and biogeographic history of the Cercideae.

Bilobate fossil leaves that are attributed to or closely compared with Bauhinia are also reported from the late Eocene of Vietnam [72], the late Eocene-early Miocene of Brazil [73], and the latest Oligocene-mid-late Miocene of Australia [74]. These records, however, have been either rejected or questioned due to lack of evidence for the pulvinus and/or basal actinodromous or acrodromous venation [30]. Paleobotanical evidence indicates that Cercis [75] and Bauhinia [30] (Table 2) had first appeared in the Eocene to Oligocene of mid-low latitudes in the Northern Hemisphere. This may more or less support a tropical Tethys Seaway (Laurasian) origin $[4,5,13]$ or an "Out of Tropical Asia" dispersal $[25,41]$ of the Cercideae and the Leguminosae as previously hypothesized. In contrast, the West Gondwana hypothesis or "Out of Africa" hypothesis for the origin of legumes [76-78] has been recently rejected by biome supertree and molecular analyses $[4,5]$. In this article, bilobate leafed fossil-species, i.e., B. ungulatoides and B. fotana, from the middle Miocene of Fujian, 
southeastern China provide some new insights into the biogeography of Bauhinia and its allies.

\section{Floristic exchanges between East Asia and South Asia}

Major collision of India with Asia in the early Cenozoic enlarged the land-area linked to Eurasia, and subsequent connection with Australasia during the Neogene led to more connections between Eurasia and Oceania [79-82], which have greatly facilitated the floristic exchanges between East Asia, South Asia, Southeast Asia and Oceania. Recent paleobotanical studies have suggested that the Sino-Indian floristic affinities have begun to be established between the tropical flora of India and (sub) tropical floras of southwestern and southeastern China during the Miocene [37, 83-85]. Our present study on the Miocene Bauhinia further supports this viewpoint.

Bilobate leaves of Bauhinia from the Miocene of southeastern China show considerable similarities with the congeneric fossil-species $[41,44]$ from the Neogene of southwestern China and India, implying that the expansion of Bauhinia from (sub) tropical East Asia to tropical South Asia might have taken place since the Miocene with the northward drift and collision of southern landmasses into Eurasia, as well as the closure of the eastern Tethys Seaway [86]. The fossils presented here further support the previous viewpoint [30] that the tropical zone [87] of South China may represent one of the centers for early diversification of Bauhinia. The bilobate and bifoliolate leaves from the Oligocene (or possibly late Eocene) Ningming Formation of Guangxi, South China [30] are the earliest, well-documented, reliable fossils of Bauhinia.

\section{Floristic exchanges between Eurasia and Africa}

Africa has been connected with Europe by the collision between the Afro-Arabian and Eurasian plates since the late Late Cretaceous [88], which facilitated floristic exchange such as the pantropical palms (Arecaceae Schultz Sch.) [78, 89]. Bauhinia and Bauhinia-like fossils previously reported from the early Paleocene to Miocene of Europe [90-95] have been either rejected or transferred to other groups [30]. Instead, some other bilobate leaf fossils that had been described as Cassia L. and Mimosa L. from the Oligocene of Germany and France [96-100] (Fig. 2CXIV-CXVII) are far more likely to represent Bauhinia. Cassia rottensis Weyland, Mimosa weberi Schimp., M. deperdita Saporta, and M. ayamadi Marion closely resemble the extant Bauhinia in their basal actinodromous or acrodromous venations. Specifically, $C$. rottensis and $M$. weberi from Germany bear great similarities with the extant African species Bauhinia morondavensis Du Puy et R. Rabev. (Fig. 2XXVIII), B. natalensis Hook. (Fig. 2XXX), and B. kalantha Harms. (Fig. 2XXXI).
Under such circumstances, Bauhinia and Bauhinialike bilobate leaf fossils from the Oligocene of Germany (Fig. 2CXIV, CXV) as well as from the middle Eocene of Tanzania [28] imply that the Bauhiniinae might have begun to exchange between Europe and Africa across the western Tethys Seaway. Bauhinia might have become depauperate and finally extinct in Europe after the Oligocene with the uplift of the Himalayan-Tibetan plateau [101], the desertification in the Asian interior [102], the establishment of the Asian monsoon system [103], and the desiccation of the Mediterranean Sea [104].

\section{Migration from Eurasia to America via the North Atlantic Land Bridge}

In America Bauhinia and Bauhinia-like bilobate leaves (Fig. 2CX, CXI) are only known from the Oligocene of Mexico [31] and the Miocene of Ecuador [40]. The Bauhina leaf from late Eocene-early Miocene of Brazil is questionable since it lacks pulvinus and the primary venation is not distinctly basal actinodromous [30]. Brazil that occupies highly diversified Bauhinia species today has been suggested as the center for origin of orchid trees [73]. However, recent molecular phylogenetic study resolved Asian species as the basalmost lineage in the genus Bauhinia whereas the neotropical species diverged during the middle Miocene [41]. The relatively extensive fossil record of Bauhinia from the late Paleogene - early Neogene of South China also supports that South China is one of the centers for early diversification of the genus.

Given that the Bauhiniinae originated in the Paleogene of low-latitudes along the eastern Tethys Seaway as we hypothesize here, it is most likely that Bauhinia and its allies migrated into North and Central America from Europe via the North Atlantic Land Bridge (NALB) [105-108]. During the early Paleogene, with the epicontinental seaways around North America and Eurasia receding, barriers between these two continents were reduced, allowing floristic exchanges of thermophilous plants to develop into a more uniform and continuous Boreotropical flora $[78,105,106,109]$. The NALB lay at lower latitude in the Paleogene-early Neogene than the Bering Land Bridge (BLB), and it may have been more favorable for tropical, subtropical or even temperate plants to migrate [107-110]. So far, Bauhinia fossils are unknown in mid-high latitudes from East Asia and North America, supporting that the BLB, situated at higher latitudes, seems not to have witnessed the migration of Bauhinia. Hence, the NALB may have been the most feasible route for migration of Bauhinia from Eurasia to North America since the late Paleogene. An alternative migration route from Eurasia to North America for (sub) tropical lineages that have recently been suggested for Smilax Havanensis group [111] might 
also apply to the presumable trans-Atlantic dispersal of Bauhinia. These authors suggested trans-Atlantic crossings at lower latitudes via "floating islands" as has also been suggested for numerous angiosperm lineages [112] and for animals (e.g., platyrrhine monkeys) [113].

It is of great interest that bilobate leaves of Bauhinia presented here from the middle Miocene of southeastern China exhibit great similarities with some extant Bauhinia species (Fig. 2XXII, XXIII) from South America, implying extensive dispersals of Bauhinia populations from Eurasia to America in or by the Miocene, during which the Isthmus of Panama was formed, facilitating the Great American Biotic Interchange [114, 115]. This inference is also consistent with the result based on molecular phylogenetic study [41], which suggests that South American Bauhinia diverged during the middle Miocene.

\section{Conclusions}

Bilobate leaf fossils, i.e., B. ungulatoides and B. fotana presented here, from the middle Miocene of southeastern China are consistent with the viewpoint that the tropical zone of South China is one of the centres for early diversification of Bauhinia, and their great similarities to some species from South Asia and South America imply that Bauhinia might have undergone extensive dispersals and diversification during the Miocene.

The reliable fossil record, extant species diversity, as well as molecular phylogenetic analyses suggest that the Bauhiniinae might have originated in the Paleogene of low-latitudes along the eastern Tethys Seaway. They dispersed southwards into Africa, migrated from Eurasia to North America via the North Atlantic Land Bridge or floating islands in southern North Atlantic during the Oligocene. Then they spread into South America via the Isthmus of Panama since the Miocene onward, and underwent regional extinctions in the Boreotropics of mid-high-latitudes by the Neogene climatic cooling, so Bauhinia presently exhibits a pantropical intercontinental disjunct distribution.

\section{Additional files}

Additional file 1: The species and distribution of Bauhinia and its allies. (PDF $266 \mathrm{~kb}$ )

Additional file 2: The list of representative species in Fig. 2.

(PDF $141 \mathrm{~kb}$ )

Additional file 3: Information on voucher specimens used in this study. (DOC $177 \mathrm{~kb}$ )

Additional file 4: Morphological analyses of leaves from illustrated species in Bauhinia and its allies. (PDF $158 \mathrm{~kb}$ )

\section{Competing interests}

The authors declare that they have no competing interests.
Authors' contributions

WOW conceived and conducted the study. ZYL, WOW, YXL, GLS and SS performed the specimen preparation, data analyses, and evolutionary interpretations. YXL, SS, GLS and WOW photographed the specimens, illustrated the line-drawings, and arranged the figures. GLS collected the type specimens. WOW, YXL and GLS wrote the manuscript and formatted the text. All authors read, revised and approved the final manuscript.

\section{Acknowledgements}

We would like to thank Dr. Rashmi Srivastava, Birbal Sahni Institute of Palaeobotany, Lucknow, Mr. Yuan Daojun, Nanjing Institute of Geology and Palaeontology, Chinese Academy of Sciences, Nanjing, and Dr. Chen Yunfa, Song Zhuqiu, Natural History Museum of Guangxi, Nanning for access to specimen collections. Dr. Susy Albert, The MS University of Baroda, Vadodara and Dr. Ruth P. Clark, Royal Botanic Gardens, Kew for helpful discussions. Academic Editor Toshihiro Yamada and two anonymous reviewers are thanked for their helpful comments. This work was supported by the National Natural Science Foundation of China (grant nos. 41372029 and 41206173) to WOW and GLS.

\section{Author details}

'State Key Laboratory of Systematic and Evolutionary Botany, Institute of Botany, Chinese Academy of Sciences, Beijing 100093, P.R. China. ${ }^{2}$ University of Chinese Academy of Sciences, Beijing 100049, P.R. China. ${ }^{3}$ State Key Laboratory of Palaeobiology and Stratigraphy, Nanjing Institute of Geology and Palaeontology, Chinese Academy of Sciences, 39 East Beijing Road, Nanjing 210008, P.R. China.

Received: 11 August 2015 Accepted: 10 November 2015 Published online: 16 November 2015

\section{References}

1. LPWG (the Legume Phylogeny Working Group). Towards a new classification system for legumes: Progress report from the $6^{\text {th }}$ International Legume Conference. S Afr J Bot. 2013;89:3-9.

2. LPWG (the Legume Phylogeny Working Group). Legume phylogeny and classification in the $21^{\text {st }}$ century: Progress, prospects and lessons for other species-rich clades. Taxon. 2013;62:217-48.

3. Lin $Y X$, Wang $Q$, Shen $S$. New advances in legume systematics. Bot Res. 2014;3:179-87.

4. Lewis G, Schrire B, Mackinder B, Lock M. Legumes of the World. Kew: The Royal Botanic Gardens; 2005. p. 1-577.

5. Schrire BD, Lavin M, Lewis GP. Global distribution patterns of the Leguminosae: Insights from recent phylogenies. Biol Skr. 2005;55:375-422.

6. Wunderlin RP, Larsen K, Larsen SS. Cercideae Bronn (1822). In: Polhill RM, Raven PH, editors. Advances in Legume Systematics, Part 1. Kew: The Royal Botanic Gardens; 1981. p. 107-16.

7. Wunderlin RP, Larsen K, Larsen SS. Reorganization of the Cercideae (Fabaceae: Caesalpinioideae). Biol Skr. 1987;28:1-40.

8. Chen TC. Bauhinia Linn. In: Wu TL, Chen PY, Wei CF, Chen TC, editors. Flora Reipublicae Popularis Sinicae, Tomus 39. Beijing: Science Press; 1988. p. 145-203.

9. Chen TC, Zhang DX, Larsen K, Larsen SS. Bauhinia Linnaeus. In: Wu ZY, Raven PH, Hong DY, editors. Flora of China, Vol. 10. Beijing: Science Press \& St. Louis: Missouri Botanical Garden Press; 2010. p. 6-21.

10. Lewis G, Forest F. Tribe Cercideae. In: Lewis G, Schrire B, Mackinder B, Lock M, editors. Legumes of the World. Kew: The Royal Botanic Gardens; 2005. p. 57-68.

11. Wunderlin RP. Reorganization of the Cercideae (Fabaceae: Caesalpinioideae). Phys Chem Chem Phys. 2010;48:1-5.

12. Bruneau $A$, Mercure M, Lewis GP, Herendeen PS. Phylogenetic patterns and diversification in the caesalpinioid legumes. Botany. 2008;86:697-718.

13. Sinou C, Forest F, Lewis GP, Bruneau A. The genus Bauhinia s.l. (Leguminosae): a phylogeny based on the plastid $t r n L-t r n F$ region. Botany. 2009:87:947-60.

14. Banks H, Forest F, Lewis $G$. Palynological contribution to the systematics and taxonomy of Bauhinia s.l. (Leguminosae: Cercideae). S African J Bot. 2013;89:219-26.

15. Mackinder BA, Clark RP. A synopsis of the Asian and Australian genus Phanera Lour. (Cercideae: Caesalpinioideae: Leguminosae) including 19 new combinations. Phytotaxa. 2014;166:49-68. 
16. Trethowan LA, Clark RP, Machinder BA. A synopsis of the neotropical genus Schnella (Cercideae: Caesalpinioideae: Leguminosae) including 12 new combinations. Phytotaxa. 2015;204:237-52.

17. George AS. Cercideae. In: McCarthy PM, editor. Flora of Australia, Volume 12, Mimosaceae (excl. Acacia), Caesalpiniaceae. Melbourne: ABRS/CSIRO Australia; 1998. p. 160-7.

18. Du Puy DJ, Labat JN, Rabevohitra R, Villiers JF, Bosser J, Moat J. The Leguminosae of Madagascar. Kew: The Royal Botanic Gardens; 2002. p. 1-737.

19. Larsen K, Larsen SS. Bauhinia L. In: Smitinand T, Larsen K, editors. Flora of Thailand, Volume 4 (1). Bangkok: The Tistr Press; 1984. p. 4-45.

20. Wunderlin RP, Eilers RM. Revision of Bauhinia subgenus Phanera section Schnella (Cercideae: Caesalpinioideae: Fabaceae). J Bot Res Inst Texas. 2009;3:619-28.

21. De Wit HCD. A revision of Malaysian Bauhinieae. Reinwardtia. 1956;3:381-539.

22. Brenan JPM. Leguminosae subfamily Caesalpinioideae. In: Milne-Redhead E, Polhill RM, editors. Flora of Tropical East Africa. London: Crown Agents for Oversea Governments and Administrations; 1967. p. 1-230.

23. Ettingshausen CV. Über die Nervation der Blätter der Papilionaceen. Sitzungsber Kais Akad Wiss Wien Math-Naturwiss Cl. 1854;12:600-63.

24. Van der Pijl L. The leaf of Bauhinia. Acta Bot Neerl. 1952;1:287-309.

25. Cusset G. Essai d'une Taxinomie Foliaire dans la Tribu des Bauhinieae. Adansonia, NS. 1966:6:251-80.

26. Fries RE. Zur Kenntnis der Blattmorphologie der Bauhinien und verwandter Gattungen. Ark Bot. 1909:8:1-16.

27. Owens SA. Secondary and tertiary pulvini in the unifolioate leaf of Cercis canadensis L. (Fabaceae) with comparison to Bauhinia purpurea L. Int J Plant Sci. 2000;161:583-97.

28. Jacobs BF, Herendeen PS. Eocene dry climate and woodland vegetation in tropical Africa reconstructed from fossil leaves from northern Tanzania. Palaeogeogr Palaeoclimatol Palaeoecol. 2004;213:115-23.

29. Chen YF, Zhang DX. Bauhinia larsenii, a fossil legume from Guangxi, China. Bot J Linn Soc. 2005;147:437-40.

30. Wang Q, Song ZQ, Chen YF, Shen S, Li ZY. Leaves and fruits of Bauhinia (Leguminosae, Caesalpinioideae, Cercideae) from the Oligocene Ningming Formation of Guangxi, South China and their biogeographic implications. BMC Evol Biol. 2014;14:88.

31. Calvillo-Canadell L, Cevallos-Ferriz SRS. Bauhcis moranii gen. et sp. nov. (Cercideae, Caesalpinioideae), an Oligocene plant from Tepexi de Rodríguez, Puebla, Mexico, with leaf architecture similar to Bauhinia and Cercis. Rev Palaeobot Palynol. 2002;122:171-84

32. Mathur AK, Mishra VP, Mehra S. Systematic study of plant fossils from Dagshai, Kasauli and Dharmsala formations of Himachal Pradesh. Geol Surv India, Palaeontol Indica, NS. 1996:50:1-121.

33. Lakhanpal RN, Guleria JS. Plant remains from the Miocene of Kachchh, western India. Palaeobotanist. 1982;30:279-96.

34. Lakhanpal RN, Guleria JS, Awasthi N. The fossil floras of Kachchh. III-Tertiary megafossils. Palaeobotanist. 1984;33:228-319.

35. Tiwari RP, Ralte VZ, Zoramthara C, Srivastava G, Mehrotra, Paul S, et al. Fossil leaves in amber from the Bhuban Formation, Mizoram, India. Himalayan Geol. 2015;36:33-8.

36. Endo S, Fujiyama I. Some late Mesozoic and late Tertiary plants and a fossil insect from Thailand. In: Kobayashi T, Toriyama R, editors. Contributions to the Geology and Palaeontology of Southeast Asia 31, Geology and Palaeontology of Southeast Asia, Volume 2. Tokyo: University of Tokyo Press; 1966. p. 191-7.

37. Jacques FMB, Shi GL, Su T, Zhou ZK. A tropical forest of the middle Miocene of Fujian (SE China) reveals Sino-Indian biogeographic affinities. Rev Palaeobot Palynol. 2015;216:76-91.

38. Antal JS, Awasthi N. Fossil flora from the Himalayan foot-hills of Darjeeling District, West Bengal, India and its palaeoecological and phytogeographical significance. Palaeobotanist. 1993;42:14-60.

39. Lakhanpal RN, Awasthi N. A late Tertiary florule from near Bhikhnathoree in West Champaran District, Bihar. In: Sharma AK, Mitra GC, Banerjee M, editors. Proceedings of the Symposium on Evolutionary Botany and Biostratigraphy, Current Trends in Life Sciences 10 (A. K. Ghosh Commemoration Volume). New Delhi: Today and Tomorrow's Printers \& Publishers; 1984. p. 587-96.

40. Berry EW. Fossil floras from southern Ecuador. Johns Hopkins Univ Stud Geol. 1945;14:93-150.

41. Meng HH, Jacques FMB, Su T, Huang YJ, Zhang ST, Ma HJ, et al. New biogeographic insight into Bauhinia s.l. (Leguminosae): integration from fossil records and molecular analyses. BMC Evol Biol. 2014;14:181.
42. Awasthi N, Prasad M. Siwalik plant fossils from Surai Khola area, western Nepal. Palaeobotanist. 1990;38:298-318.

43. Chaney RW. A tertiary flora from Uganda. J Geol. 1933;41:702-9.

44. Bande MB, Srivastava GP. Late Cenozoic plant-impressions from Mahuadnar Valley, Palamu District, Bihar. Palaeobotanist. 1990;37:331-66.

45. Zheng YH. Marginipollis (Lecythidaceae) from the upper Tertiary Fotan Group in southern Fujian. Acta Palaeontol Sin. 1984;23:764-7.

46. Zheng YH, Wang WX. Sequence of Miocene Fotan Group in SE Fujian and its palyno-assemblages. Acta Palaeontol Sin. 1994;33:200-16.

47. Shi GL, Li HM. A fossil fruit wing of Dipterocarpus from the middle Miocene of Fujian, China and its palaeoclimatic significance. Rev Palaeobot Palynol. 2010;162:599-606.

48. Shi GL, Jacques FMB, Li HM. Winged fruits of Shorea (Dipterocarpaceae) from the Miocene of Southeast China: Evidence for the northward extension of dipterocarps during the Mid-Miocene Climatic Optimum. Rev Palaeobot Palynol. 2014;200:97-107.

49. Ho K, Chen J, Lo C, Zhao H. ${ }^{40} \mathrm{Ar} /{ }^{39} \mathrm{Ar}$ dating and geochemical characteristics of late Cenozoic basaltic rocks from the Zhejiang-Fujian region, SE China: eruption ages, magma evolution and petrogenesis. Chem Geol. 2003;197:287-318.

50. Shi GL, Zhou ZY, Xie ZM. A new Cephalotaxus and associated epiphyllous fungi from the Oligocene of Guangxi, South China. Rev Palaeobot Palynol. 2010;161:179-95

51. International Legume Database \& Information Service (ILDIS). Cardiff: Cardiff School of Computer Science \& Informatics. Published on the internet [http://www.ildis.org/ildis/index.shtml] (Accessed on November 13, 2015).

52. eFloras.org. St. Louis: Missouri Botanical Garden \& Cambridge: Harvard University Herbaria. Published on the internet [http://www.efloras.org/] (Accessed on November 13, 2015).

53. Chinese Virtual Herbarium (CVH). A National Taxonomic Database. Beijing: Institute of Botany, Chinese Academy of Sciences. Published on the internet [http://www.cvh.ac.cn/] (Accessed on November 13, 2015).

54. Index Herbariorum. Bronx: The New York Botanical Garden. Published on the internet [http://sweetgum.nybg.org/ih/] (Accessed on November 13, 2015).

55. The International Plant Names Index. Published on the internet [http://www.ipni.org] (Accessed on November 13, 2015).

56. Ellis B, Daly DC, Hickey LJ, Johnson KR, Mitchell JD, Wilf $P$, et al. Manual of Leaf Architecture. Ithaca \& New York: Cornell University Press; 2009. p. 1-190.

57. Dilcher DL. Approaches to the identification of angiosperm leaf remains. Bot Rev. 1974;40:1-157

58. Cohen KM, Finney SC, Gibbard PL, Fan JX. The ICS International Chronostratigraphic Chart. Episodes 2013;36:199-204.

59. Kincaid DT, Schneider RB. Quantification of leaf shape with a microcomputer and Fourier transform. Can J Bot. 1983;61:2333-42.

60. McLellan T, Endler JA. The relative success of some methods for measuring and describing the shape of complex objects. Syst Biol. 1998;47:264-81.

61. Juneau KJ, Tarasoff CS. Leaf area and water content changes after permanent and temporary storage. PLoS One 2012;7:e42604.

62. Kotresha K, Seetharam YN. Epidermal studies in some species of Bauhinia (Caesalpinioideae). Phytomorphology 1995;45:127-37.

63. Lusa MG, Bona C. Análise morfoanatômica comparativa da folha de Bauhinia forficata Link e B. variegata Linn. (Leguminosae, Caesalpinioideae). Acta Bot Bras. 2009;23:196-211.

64. Albert S, Sharma B. Comparative foliar micromorphological studies of some Bauhinia (Leguminosae) species. Turk J Bot. 2013;37:276-81.

65. Aworinde DO, Fawibe OO. Taxonomic significance of foliar epidermal characters in the Caesalpinioideae. Afr J Plant Sci. 2014;8:462-72.

66. Duarte-Almeida JM, Clemente MS, Arruda RCO, Vaz AMSF, Salatino A. Glands on the foliar surfaces of tribe Cercideae (Caesalpiniodeae, Leguminosae): distribution and taxonomic significance. An Acad Bras Cienc. 2015:87:787-96

67. Vieira RC, Machado RD. Superfície Foliar de Bauhinia radiata Vell. em dois Ambientes. Hoehnea 1992;19:111-6.

68. Rezende MH, Cardoso LA, Vannucci AL. Morfologia e Anatomia Foliar de Bauhinia curvula Benth. (Leguminosae-Caesalpinioideae). Acta Bot Bras. 1994:8:19-34.

69. Castro S, Silveira P, Coutinho AP, Figueiredo E. Systematic studies in Tylosema (Leguminosae). Bot J Linn Soc. 2005;147:99-115.

70. McNeill J, Barrie FR, Buck WR, Demoulin V, Greuter W, Hawksworth DL, et al. International Code of Nomenclature for Algae, Fungi, and Plants 
(Melbourne Code) Adopted by the Eighteenth International Botanical Congress Melbourne, Australia, July 2011, Regnum Vegetabile 154. Königstein: Koeltz Scientific Books; 2012. p. 1-208.

71. Fritsch PW, Cruz BC. Phylogeny of Cercis based upon DNA sequences of nuclear ITS and four plastid regions: Implications for transatlantic historical biogeography. Mol Phylogen Evol. 2012;60:816-25.

72. Böhme M, Aiglstorfer M, Antoine P-O, Appel E, Havlik P, Métais G, et al. Na Duong (northern Vietnam)-an exceptional window into Eocene ecosystems from Southeast Asia. Zitteliana A 2013;53:121-67.

73. Biagolini $\mathrm{CH}$, Bernardes-de-Oliveira MEC, Caramês AG. Itaquaquecetuba Formation, São Paulo basin, Brazil: new angiosperm components of Paleogene taphoflora. Braz J Geol. 2013;43:639-52.

74. Carpenter RJ, Goodwin MP, Hill RS, Kanold K. Silcrete plant fossils from Lightning Ridge, New South Wales: New evidence for climate change and monsoon elements in the Australian Cenozoic. Austral J Bot. 2011;59:399-425.

75. Jia H, Manchester SR. Fossil leaves and fruits of Cercis (Leguminosae) from the Eocene of western North America. Int J Plant Sci. 2014;175:601-12.

76. Raven PH, Axelrod DI. Angiosperm biogeography and past continental movements. Ann Missouri Bot Gard. 1974;61:539-657.

77. Raven PH, Polhill RM. Biogeography of the Leguminosae. In: Polhill RM, Raven PH, editors. Advances in Legume Systematics, Part 1. Kew: The Royal Botanic Gardens; 1981. p. 27-34.

78. Morley RJ. Interplate dispersal paths for megathermal angiosperms. Perspect PI Ecol Evol Syst. 2003;6:5-20.

79. Hall R. Cenozoic geological and plate tectonic evolution of SE Asia and the SW Pacific: Computer-based reconstructions, model and animations. J Asian Earth Sci. 2002;20:353-431.

80. Crame JA, Rosen BR. Cenozoic palaeogeography and the rise of modern biodiversity change. In: Crame JA, Owen AW, editors. Palaeobiogeography and Biodiversity Change: The Ordovician and Mesozoic-Cenozoic Radiations. London: Geological Society, Special Publications 194; 2002. p. 153-68.

81. Metcalfe I. Tectonic history of the SE Asian-Australian region. In: Kershaw P, David B, Tapper N, editors. Bridging Wallace's Line: The Environmental and Cultural History and Dynamics of the SE-Asian-Australian Region. Reiskichen: Catena Verlag. Advances in GeoEcology 34; 2002. p. 29-48.

82. Chatterjee S, Goswami A, Scotese CR. The longest voyage: tectonic, magmatic, and palaeoclimatic evolution of Indian plate during its northward flight from Gondwana to Asia. Gondwana Res. 2013;23:238-67.

83. Tao JR, Zhou ZK, Liu YS. The Evolution of the Late Cretaceous-Cenozoic Floras in China. Beijing: Science Press; 2000. p. 1-282.

84. Wang Q, Manchester SR, Dilcher DL. Fruits and foliage of Pueraria (Leguminosae, Papilionoideae) from the Neogene of Eurasia and their biogeographic implications. Am J Bot. 2010;97:1982-98.

85. Mehrotra RC, Liu XQ, Li CS, Wang YF, Chauhan MS. Comparison of the Tertiary flora of Southwest China and Northeast India and its significance in the antiquity of the modern Himalayan flora. Rev Palaeobot Palynol. 2005; 135:145-63.

86. Hamon N, Sepulchre P, Lefebvre V, Ramstein G. The role of eastern Tethys seaway closure in the Middle Miocene Climatic Transition (ca. 14 Ma). Clim Past. 2013;9:2687-702.

87. Zhu H. Geographical elements of seed plants suggest the boundary of tropical zone in China. Palaeogeogr Palaeoclimatol Palaeoecol. 2013;386:16-22.

88. Ezcurra MD, Agnolín FL. A new global palaeobiogeographical model for the Late Mesozoic and early Tertiary. Syst Biol. 2012;61:553-66.

89. Srivastava R, Srivastava G, Dilcher DL. Coryphoid palm leaf fossils from the Maastrichtian-Danian of Central India with remarks on phytogeography of the Coryphoideae (Arecaceae). PLoS One 2014;9:e111738.

90. Seward AC, Conway V. Additional Cretaceous plants from western Greenland. Kungl Svenska Vetenskapsakad Handl. 1935:15:3-41.

91. Reid EM, Chandler MEJ. The London Clay Flora. London: British Museum (Natural History); 1933. p. 1-561.

92. Engelhardt H. Die Alttertiäre Flora von Messel bei Darmstadt. Abh Hess Geol Landesanst Darmstadt 1922;7:17-128.

93. Unger F. Sylloge Plantarum Fossilium. Denkschr Kaiserl Akad Wiss Wien, Math-Naturwiss Kl. 1864;22:1-36.

94. Unger F. Die Fossile Flora von Kumi auf der Insel Euboea. Wien: Aus der Kaiserlich-Königlichen Hof- und Staatsdruckerei; 1867. p. 1-66.
95. Heer O. Die Tertiäre Flora der Schweiz, Flora Tertiaria Helvetiae, Vol. 3 (6). Winterthur: Verlag der Lithographischen Anstalt von Wurster \& Comp; 1857. p. 1-200.

96. Wessel P, Weber O. Neuer Beitrag zur Tertiärflora der Niederrheinischen Braunkohlenformation. Palaeontographica 1856:4:111-68.

97. Weyland H. Beiträge zur Kenntnis der Rheinischen Tertiärflora II. Erste Ergänzungen und Berichtigungen zur Flora der Blätterkohle und des Polierschiefers von Rott im Siebengebirge. Palaeontogr. Abt B. 1937;83:67-122.

98. Saporta G. Études sur la Végétation du Sud-Est de la France a L'Époque Tertiaire, III Flore des lignites inférieurs, ou étage à lignite proprement dit. Ann Sci Nat, Sér 4 Bot. 1862;17:191-311.

99. Marion AF. Description des Plantes Fossiles des Calcaires Marneux de Ronzon (Haute-Loire). Ann Sci Nat, Sér 5 Bot. 1872;14:326-64.

100. Schimper WP. Traité De Paléontologie Végétale, III, IV. Paris: J. B. Baillière et Fils; 1874. p. 398-9. plate 106.

101. An ZS, Kutzbach JE, Prell WL, Porter SC. Evolution of Asian monsoons and phased uplift of the Himalayan-Tibetan plateau since late Miocene times. Nature. 2001:411:62-6.

102. Guo ZT, Ruddiman WF, Hao QZ, Wu HB, Qiao YS, Zhu RX, et al. Onset of Asian desertification by $22 \mathrm{Myr}$ ago inferred from loess deposits in China. Nature 2002:416:159-63.

103. Sun XJ, Wang PX. How old is the Asian monsoon system? Paleobotanical records from China. Palaeogeogr Palaeoclimatol Palaeoecol. 2005;222:181-222.

104. Fauquette S, Suc J-P, Bertini A, Popescu SM, Warny S, Bachiri Taoufiq N, et al. How much did climate force the Messinian salinity crisis? Quantified climatic conditions from pollen records in the Mediterranean region. Palaeogeogr Palaeoclimatol Palaeoecol. 2006;238:281-301.

105. Tiffney $\mathrm{BH}$. Perspectives on the origin of the floristic similarity between eastern Asia and eastern North America. J Arnold Arbor. 1985:66:73-94.

106. Tiffney BH, Manchester SR. The use of geological and paleontological evidence in evaluating plant phytogeographic hypotheses in the Northern Hemisphere Tertiary. Int J Plant Sci. 2001;162:S3-17.

107. Tiffney $\mathrm{BH}$. The Eocene North Atlantic Land Bridge: its importance in Tertiary and modern phytogeography of the Northern Hemisphere. J Arnold Arbor. 1985;66:243-73.

108. Milne Rl, Abbott RJ. The origin and evolution of Tertiary relict floras. Adv Bot Res. 2002;38:281-314.

109. Wolfe JA. Some aspects of plant geography of the northern hemisphere during the Late Cretaceous and Tertiary. Ann Missouri Bot Gard. 1975;62:264-79.

110. Denk T, Grímmson F, Zetter R. Episodic migration of oaks to Iceland: Evidence for a North Atlantic "land bridge" in the latest Miocene. Am J Bot. 2010;97:276-87.

111. Denk T, Velitzelos D, Güner HT, Ferrufino-Acosta L. Smilax from the Miocene of the eastern Mediterranean with Caribbean biogeographic affinities. Am J Bot. 2015;102:423-38

112. Renner S. Plant dispersal across the tropical Atlantic by wind and sea currents. Int J Plant Sci. 2004:165:S23-33.

113. Houle A. Floating islands: a mode of long-distance dispersal for small and medium-sized terrestrial vertebrates. Divers Distrib. 1998:4:201-16.

114. Leigh EG, O'Dea A, Vermeij GJ. Historical biogeography of the Isthmus of Panama. Biol Rev. 2014;89:148-72.

115. Webb SD. The Great American Biotic Interchange: patterns and processes. Ann Missouri Bot Gard. 2006;93:245-57. 